\title{
Üç Anzak Ressamın Gözüyle Çanakkale Muharebesi
}

\author{
The Battle of Çanakkale Through The Eyes of Three Anzac Painters
}

\section{Simge Özer Pınarbaşı ‘}

Öz

Çanakkale, Birinci Dünya Savaşı sırasında önemli bir cephelerden biridir. Çanakkale muharebeleri 3 Kasım 1914 - 9 Ocak 1916 tarihleri arasında gerçekleşmiştir. 18 Mart 1915'te güçlü Osmanlı savunmasıyla bozguna uğrayan İtilaf Devletleri, karadan destek almadan yalnızca deniz kuvvetleriyle boğazın geçilemeyeceğini anladıklarından bir çıkarma ordusu hazırlamaya koyulmuşlardır. İngiltere bu çıkarma için sömürgelerinden olan Avustralya ve Yeni Zelanda'dan asker toplamak amacıyla propaganda çalışmalarına başlamıştır. Toplanan bu askerlere Avustralya ve Yeni Zelanda Kolordosu'nun İngilizce başharflerinden oluşan ANZAC (Australian \& New Zealand Army Corps) adı verilmiştir. Bu askerler arasında ressamlar da bulunuyordu.

Bu çalışmada Anzak ressamlardan Horace Millichamp Moore-Jones, Frank Rossiter Crozier ve George Washington Thomas Lambert'in resimleri incelenmiştir. Üç ressamdan ikisi fiilen savaşa katılmış olup, biri yenilgiden sonra Çanakkale'ye gönderilmiştir. Fiilen savaşa katılanlardan Horace Millichamp Moore-Jones resimlerinde savaşı yorumlamak yerine belgelemekle yetinmiştir. Savaşta sedye taşıyıcısı olarak görev yapan Frank Rossiter Crozier'in illüstrasyonlarında ise vatan özlemi, umutsuzluk gibi temalar görülmektedir. 1919'da özel izinle buraya gelip savaş sahneleri, portreler betimleyen resmî savaş ressamı George Washington Thomas Lambert'in resimleri Anzak işgalinin ülkesi için ağır sonuçlarını yansıtmaktadır. Çanakkale Savaşı'nı betimleyen üç Anzak ressamın da farklı tutumları olduğu görülmektedir.

\section{Anahtar Kelimeler}

Anzak, Çanakkale, Horace Millichamp Moore-Jones, Frank Rossiter Crozier, George Washington Thomas Lambert

\begin{abstract}
An important front during the First World War was Çanakkale. Çanakkale battles took place between November 3,1914 and January 9, 1916. The Allied Powers, after being defeated by the strong Ottoman defense on March 18, 1915, began to prepare a landing army, as they realized that the strait could not be crossed by naval forces without land support. Britain started propaganda efforts to recruit soldiers from its colonies, Australia and New Zealand, for this landing. This collection of soldiers were nicknamed Anzac, for the English initials of the Australian and New Zealand Corps (Australian \& New Zealand Army Corps). These Anzac troops included the painters Horace Millichamp Moore-Jones, Frank Rossiter Crozier, and George Washington Thomas Lambert, whose lives and paintings will be discussed in this paper. Two of the painters took part in the war, and one was sent to Çanakkale after defeat. Horace Millichamp Moore-Jones, one of the soldiers active in the battle, found it sufficient to document the war visually instead of commenting on it verbally. In the illustrations of Frank Rossiter Crozier, who served as a stretcher bearer in the war, themes such as homesickness and despair are seen. The paintings of the official war painter George Washington Thomas Lambert, who came with special permission after the defeat in 1919 and depicted war scenes and portraits, are interesting in terms of showing the Anzacs'
\end{abstract}

* Sorumlu Yazar: Simge Özer Pınarbaşı (Doç. Dr.) İstanbul Üniversitesi Edebiyat Fakültesi Sanat Tarihi Bölümü. İstanbul, Türkiye. E-posta: simge@istanbul.edu.tr, ORCID: 0000-0003-2761-454X

Atıf: Ozer Pinarbasi, Simge. "Üç Anzak Ressamın Gözüyle Çanakkale Muharebesi." Art-Sanat, 16(2021): 465-489. https://doi.org/10.26650/artsanat.2021.16.0016 
view of the region after defeat. Lambert's paintings reflect the grave consequences of the Anzac occupation for his country. Each of these three Anzac painters who depicted the Battle of Çanakkale in Gallipoli Peninsula reveal different attitudes about the conflict.

Keywords

Anzac, Çanakkale, Horace Millichamp Moore-Jones, Frank Rossiter Crozier, George Washington Thomas Lambert

\section{Extended Summary}

The battles that took place in the Dardanelles between November 3, 1914 and January 9, 1916 were among the most important military activities of the First World War. The Allied Powers, which were defeated by the strong Ottoman defense on March 18, 1915, began to prepare a landing army as they realized that crossing the strait would require naval and land forces. Britain started propaganda efforts to recruit soldiers from its colonies, Australia and New Zealand, for this landing. These Anzac troops (Australian \& New Zealand Army Corps) were brought to Egypt in December 1914 then transported by ship to the Gallipoli peninsula.

While there were many painters among these soldiers, there is no study about Anzac painters in Turkey. The examination of their works is important in terms of art as well as military history. However, since examining all of the Anzac painters, which are quite numerous, would exceed the dimensions of this study, three were selected, and different perspectives were revealed by examining their works. Disparate paintings have been selected to reflect the fact that the painters are artists using different techniques. Horace Millichamp Moore-Jones (1868-1922) used watercolor, Frank Rossiter Crozier (1883-1948) used drawing in his illustrations, and George Washington Thomas Lambert (1873-1930) used oil painting. The first two of these painters participated in the war, and the last one came to Çanakkale after the defeat with special permission.

The paintings of Horace Millichamp Moore-Jones are like diaries of the Gallipoli Battle. The artist>s paintings are matched with historical sources describing the Gallipoli War, demonstrating the stages of war. These paintings in sketch or watercolor technique are examples of war painting, which is an old tradition in the West. They served practical rather than aesthetic purposes, and they are also a kind of espionage showing topographical features and enemy ranges. There are no psychological elements in these pictures. The artist did not include any details that would express his feelings during the war or create an emotion in the audience.

However, Frank Rossiter Crozierss illustrations for The Anzac Book reflect the psychological effects of this war on Anzac soldiers as time passed. Many soldiers believed they would win easily but then began to fall into despair, the longing of their homeland and the people they left behind beginning to dominate as they realized the 
frightening face of the war. Reflecting an emotional point of view, Crozierss paintings depict the psychology of soldiers in all their reality. Just as Horace Jones kept a diary of the battle, Crozier showed the changing mental states of the warriors from day to day.

Apart from these two Anzac painters who came to fight in Çanakkale, the official war painter George Washington Thomas Lambert, who came here with special permission in 1919 after the defeat, is interesting in terms of showing the war scenes and portraits depicting Anzacs〉 view after the war. Lambert's images display the Anzacs' landing in Gallipoli in Kabatepe on April 25, 1915. Contrary to Moore-Jones, who personally participated in the war, this picture he designed with him imagination shows the moment when the Australian troops climbed the rocky hills (Kabatepe). The soldiers climbing the rocky terrain are hardly noticed with their green uniforms disappearing in the landscape. Some of the soldiers fell to the ground or are shown dead. The smoke of the Turks' cannon fire on the hills also gives clues about the cause of these deaths.

It is seen that the three Anzac painters who depicted the Gallipoli War also had different attitudes. Horace Millichamp Moore-Jones, who changed his appereance to be looked younger and joined the war with great enthusiasm, kept a diary of the war in his paintings. The purpose of these paintings showing the fronts and the positions of the armies was undoubtedly not artistic but military. These pictures, which were probably painted with the artist hidden or looking from a distance with binoculars to give information about enemy positions, were also aimed at some kind of military espionage. Therefore, they were pictures that did not include the psychological dimension. However, Frank Rossiter Crozier's illustrations for The Anzac Book reflect the psychological effects of this war on Anzac soldiers as time passed. Reflecting an emotional point of view, Crozier's paintings depict the psychology of soldiers in all their reality. The paintings of the official war painter George Washington Thomas Lambert, who came to Çanakkale with special permission in 1919 after the First World War that ended in 1918 and made large canvas paintings after researching, reflect the heavy consequences of the Anzac occupation for the country by illustrating the mass casualties at the battlefield. However, it still does not include the psychological dimension. It is content with documenting the historical facts of the war. It may be surprising Australians wanted to document their defeat by sending a war painter to Çanakkale. However, this war was a very important turning point as it enabled Australians to exist on the world stage and paved the way for them to become a nation. Therefore, it is not surprising that they sent the official war painters and ordered these paintings. 


\section{Giriş}

3 Kasım 1914 - 9 Ocak 1916 tarihleri arasında Çanakkale Boğazı'nda gerçekleşen muharebeler, Birinci Dünya Savaşı'nın en önemli askerî faaliyetlerindendir. Osman11 Devleti'nin Almanya yanında savaşa katılmasıyla zor durumda kalan İngiltere ve Fransa, İstanbul'u ele geçirmek ve Osmanlılar'ı saf dışı bırakmak için bu harekatın gerekli olduğunu düşünerek 3 Kasım 1914'te saldırıya geçmiştir. Boğazlar'a yönelik bu harekatın ilk deniz hücumu iki İngiliz harp gemisinin Ertuğrul ve Seddülbahir tabyalarını, iki Fransız gemisinin de Kumkale ve Orhaniye tabyalarını bombardıman etmesiyle başlamıştır. Resmen savaş ilan edilmeden başlatılan bu saldırı, hedefin Boğazlar olacağını göstermektedir. Nitekim iki gün sonra 5 Kasım 1914'te İtilaf Devletleri (Fransa ve İngiltere) Osmanlı devletine savaş ilan etmiştir. İkinci hücumlarını ise 19 Şubat 1915'te boğazın gerisindeki Türk tabyalarını uzaktan topçu ateşine tutarak gerçekleştirmişlerdir. İtilaf Devletleri'nin 17 Mart'ta mayınlardan temizlediklerini düşündükleri boğazın Karanlık Liman bölgesi, Türk donanmasına ait Nusret mayın gemisi tarafından mayınlanmıştır. Böylece 18 Mart 1915'te Boğaz'a giren İngiliz ve Fransız filoları iki yakadaki Türk mevzilerinden açılan yoğun ateş ve mayınların etkisiyle mevcutlarının \% 35'ini kaybedip çekilmişlerdir. Güçlü Osmanlı savunmasıyla bozguna uğrayan İtilaf Devletleri, karadan destek almadan yalnızca deniz kuvvetleriyle Boğaz'ın geçilemeyeceğini anladıklarından bir çıkarma ordusu hazırlamaya koyulmuşlardır ${ }^{1}$. İngiltere, bu çıkarma için sömürgelerinden olan Avustralya ve Yeni Zelanda'dan asker toplamak amacıyla propaganda çalışmalarına başlamıştır. Bu propagandalarda Osmanlıların bir tür kanser olduğu ve defedilmeleri gerektiği vurgulanmıştır. Toplanan bu askerlere Avustralya ve Yeni Zelanda Kolordosu'nun İngilizce başharflerinden oluşan ANZAC (Australian \& New Zealand Army Corps) adı verilmiştir. Askerler 1914 yılının Aralık ayında Mısır'a getirilmiş ve gemilerle Gelibolu yarımadasına taşınmışlardır².

Gelibolu'ya gelen Anzak askerlerinin arasında ressamlar da bulunuyordu. Birinci Dünya Savaşı sırasında orduda görev alan Anzak resmi savaş sanatçılarının sayısı Australian War Memorial'de belirtildiğine göre 15 ressam ve üç heykeltraştan oluşmaktaydı ve bunlar sanat eğitimi almış kişilerdi ${ }^{3}$. Anzak ressamlarla ilgili ülkemizde yapılmış herhangi bir çalışmaya rastlanmamıştır. Dolayısıyla bu ressamların tarihimizin önemli bir savaşını konu alan resimlerinin incelenmesi, askerî tarih açısından olduğu kadar sanat tarihi bakımından da önem taşımaktadır. Ancak sayıları oldukça fazla

1 Zekeriya Kurşun, "Çanakkale Muharebeleri", Íslam Ansiklopedisi, c. 8, (İstanbul: Türkiye Diyanet Vakfı Yayınları, 1993), 205-206.

2 Cengiz Özakıncı, "25 Nisan 1985 Arıburnu, Anzak koyu, Mehmetçik ve Coniler", Bütün Dünya 4 (2016), $57-58$.

3 "Australian Official War Artists", Australian War Memorial, erişim 21 Haziran 2121, https://www.awm.gov. au/articles/encyclopedia/war_artists/ww1 
olan Anzak ressamların tümünü incelemek bu çalışmanın boyutlarını aşacağından aralarından üçü seçilmiş ve yapitları incelenerek farklı bakış açıları ortaya konulmuştur. Seçim yapılırken ressamların farklı teknikler kullanan sanatçılar olmasına dikkat edilmiş, böylece birbirine benzemeyen resimler gösterilmiştir. Seçilen üç ressamın kullandıkları resim teknikleri birbirinden farklıdır. Horace Millichamp Moore-Jones (1868-1922) suluboya, Frank Rossiter Crozier (1883-1948) illüstrasyonlarda kullanılmak üzere çizim, George Washington Thomas Lambert (1873-1930) ise yağlıboya tekniğini kullanmışlardır. Bu ressamlardan ilk ikisi savaşa fiilen katılmış, sonuncusu ise yenilginin ardından özel izinle Çanakkale'ye gelmiştir. Horace Jones'un resimleri savaşın önemli anlarını yansıttığından onun resimlerine daha çok yer verilmiş, öteki sanatçıların resimleri ise benzer örnekleri yinelememek için kısıtlı tutulmuştur. Ele alınan sanatçıların resimleri Avusturalya' da çeşitli müze ve arşivlerde bulunmaktadır. Dijital ortama aktarılmış olan bu koleksiyonlar incelenerek bu çalışmada kullanılan örnekler seçilmiş̧ir. Resimlerde gösterilen yerlerin adları ve bunları doğrulayan fotoğraflar için Çanakkale Muharebeleri'ni konu alan bir dijital kaynaktan ${ }^{4}$ yararlanılmıştır.

\section{Horace Millichamp Moore-Jones}

Anzak ressamların arasında savaşa gitmek için son derece istekli olduğu, yaşı ilerlemiş olmasına karşın bıyığını ve saçını kesip yaşı hakkında yalan söyleyerek orduya katılmasından ${ }^{5}$ anlaşılan Horace Millichamp Moore-Jones, resimleriyle savaşın âdeta günlüğünü tutmuştur. Sanatçının resimleriyle Çanakkale Savaşı'nı anlatan tarihsel kaynaklar eşleştirildiğinde savaşın aşamaları görülebilmektedir.

Horace Jones aslında İngiltere'de Worcestershire'de doğmuş, muhtemelen ailesiyle 1885 y1lında Yeni Zelanda'da Auckland'e yerleşmiştir. Orada ressam ve heykeltraş Anne Dobson'dan resim dersleri almış ve sonra onunla evlenerek Avustralya'ya -Sydney'e- taşınmıştır. 1892-1905 yılları arasında çeşitli resimlerini sergilemiş ve bu dönemde adını değiştirerek Horace Millichamp Moore-Jones adını almıştır. Karısı 1901'de ölmüş, 1902'de ilk savaş resmi olan Dokuzuncu Birliğin Güney Afrika Savaşı için Yeni Zelanda'dan Ayrılışı adlı yağlıboya resmi Auckland Sanat Galerisi'nde sergilenmiştir. 1905 'te tekrar evlenen Jones, 1908'de Auckland'e ailesinin yanına dönmüştür. 1912'de Londra'ya bir gezi yapmış, orada Slade School of Fine Art'a kaydolmuş ve Pearson's Magazine'de çalışmaya başlamıştır. 1914'te orduya katılmıştır'. Savaştan sonra 1918'de Hamilton High School'da resim hocalı̆̆1 yapmaya başlamış, ailesi Auckland'de olduğu için Hamilton Oteli'nde kalmış, hafta sonlarını ailesiyle

4 "Çanakkale Muharebeleri", Çanakkale Muharebeleri, erişim 5 Ağustos 2018, https://canakkalemuharebeleri 1915.com/

5 Anne Gray, "Moore-Jones, Horace Millichamp", Dictionary of New Zealand Biography, Erişim 5 Ağustos 2018, https://teara.govt.nz/en/biographies/3m60/moore-jones-horace-millichamp

6 Gray, "Moore-Jones, Horace Millichamp", https:/teara.govt.nz/en/biographies/3m60/moore-jones-horacemillichamp 
geçirmiştir. 3 Nisan 1922'de otelin mutfağında çıkan bir yangında konuklardan bazılarını kurtarmış, otel hizmetçilerinden birinin içeride kaldığını sanarak yanan binaya tekrar girmiş ve ağır biçimde yaralanmış ve hastanede yaşamını yitirmiştir? ${ }^{7}$ Sanatçı, savaş resimlerinin yanı sıra manzaralar ve portreler de yapmıştır. Bu resimlerde İzlenimciler'in tekniğini anımsatan belirgin firça darbeleri dikkati çekmektedir. En tanınmış yapıtı olan Er Simpson ve Eşeği adlı resmini fotoğraftan bakarak çizmiştir̊.

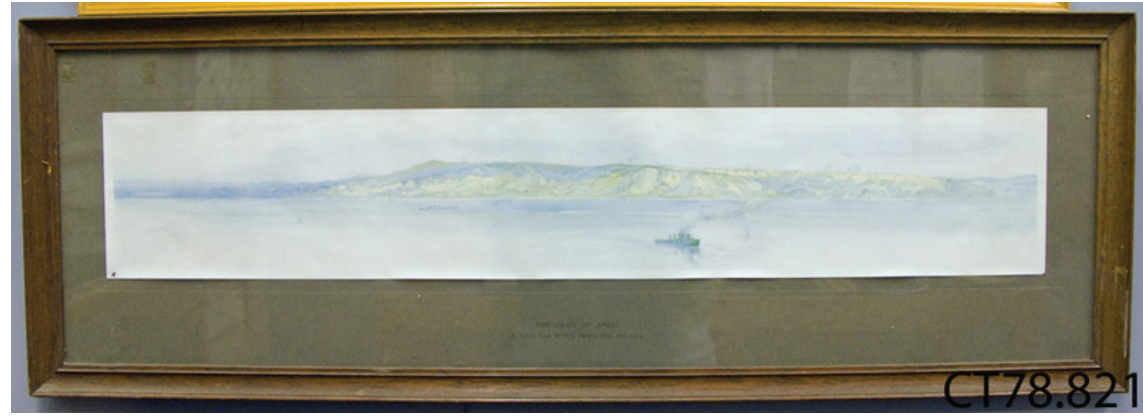

G. 1: Horace Millichamp Moore-Jones, Anzak Koyu, 1915, Karton üzerine suluboya, 184x29 cm., Owaka Museum (https://www.nzmuseums.co.nz/collections/3021/objects/74184/print-thecoast-of-anzac)

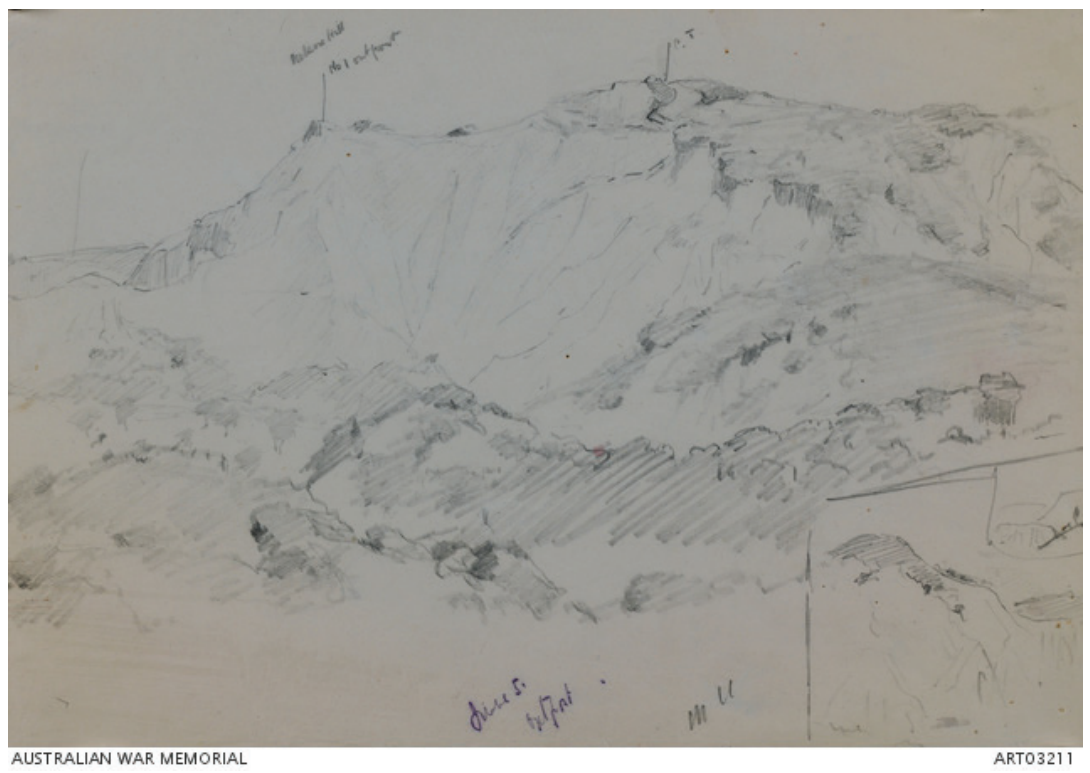

G. 2: Horace Millichamp Moore-Jones, Karakol No.1 Nelson Tepesi, 1915, Kağıt üzerine kurşun kalem, 13.8x19.6 cm., Australian War Memorial, Campbell

(https://www.awm.gov.au/collection/C172794)

7 Jennifer Haworth, Behind the Twisted Wire: New Zealand Artists in World War I, (Christchurch, New Zealand: Wily Publications, 2016), 66-67.

8 "Man With The Donkey", Evening Post, 15 September 1937, erişim 15 Mayıs 2021, https://paperspast.natlib. govt.nz/newspapers/EP19370915.2.53 


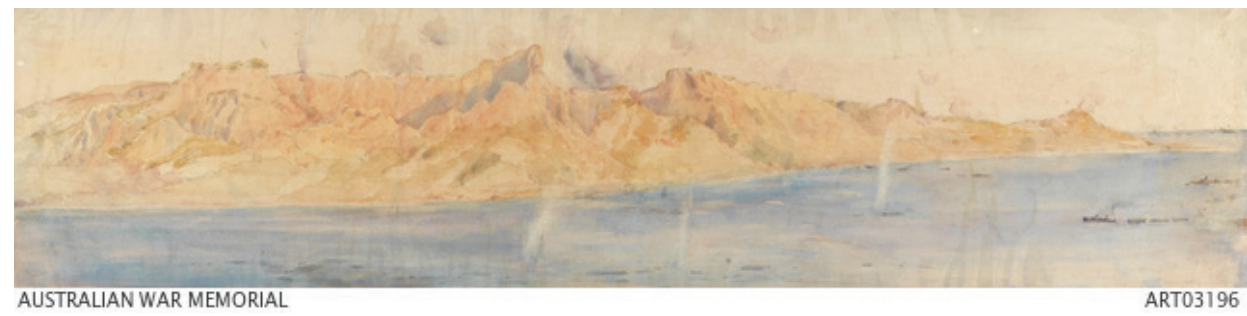

G. 3: Horace Millichamp Moore-Jones, Plugge Platosu'nun Tepeleri, Walker Sirtı ve Sfenks Gelibolu, 1915, Kağıt üzerine kalem ve suluboya, 19.3 x 77.7 cm., Australian War Memorial, Campbell (https://www.awm.gov.au/collection/C172822)

Jones, orduya katılınca önce Salisbury'de eğitim almış, sonra Mısır'a gitmiştir'. Mısır'dan gemilerle yola çıkan Anzak birliklerinin de aralarında olduğu İngiliz ve Fransız kuvvetleri 25 Nisan 1915 günü sabaha karşı çıkarma harekatına başlamışlardır ${ }^{10}$. Horace Jones'un 5 Mayıs 1915 tarihli suluboya manzarası gemiden bakarak yapılmış gibi görünen panoramik bir manzaradır ve kıyının topoğrafik özelliklerini yansıtmaktadır (G. 1). Jones, buraya varır varmaz General Sir William Birdwood'un komutasındaki ANZAC Printing Bölümü'nde ${ }^{11}$ müttefiklerin planlarını ve Türk ordusunun pozisyonlarını gösteren topoğrafik karakalem ve suluboya manzara eskizleri yapmakla görevlendirilmiştir. Arazi zorlu koşullara sahip olduğundan bu resimler ordunun operasyon planlarında önemli bir yardımcıdır. Arazide yapılan bu eskizlerin daha sonra suluboyaya geçirildiği anlaşılmaktadır. Nitekim sanatçının, Kasım 1915'te sağ elinden yaralanınca geçici olarak çalışmalarına son verdiği, Birmingham'da hastanede yattıktan sonra eskizlerini suluboyaya geçirdiği belirtilmiştir ${ }^{12}$. Dolayısıyla arazide yapılan bu eskizlerin amacının topoğrafyayı öğrenmek ve Türk siper pozisyonlarını göstermek olduğu söylenebilir. Ayrıca günümüze gelebilen üstüne notlar alınmış bazı karakalem eskizleri de bunu doğrulamaktadır (G. 2).

9 Gray, "Moore-Jones, Horace Millichamp", https://teara.govt.nz/en/biographies/3m60/moore-jones-horacemillichamp

10 Kurşun, "Çanakkale Muharebeleri", 206.

11 Printing Bölümü I. Dünya Savaşı sırasında İngiliz Ordusu tarafından kurulan The Army Printing and Stationery Service ünitesidir. Görevleri mevcut yayınların sahadaki birimlere dağıtımını düzenlemek, kendi yayınlarını hazırlayıp basmak, kartpostal, kırtasiye malzemeleri ve kitapları dağıtmaktı.

12 Gray, "Moore-Jones, Horace Millichamp", https:/teara.govt.nz/en/biographies/3m60/moore-jones-horacemillichamp 


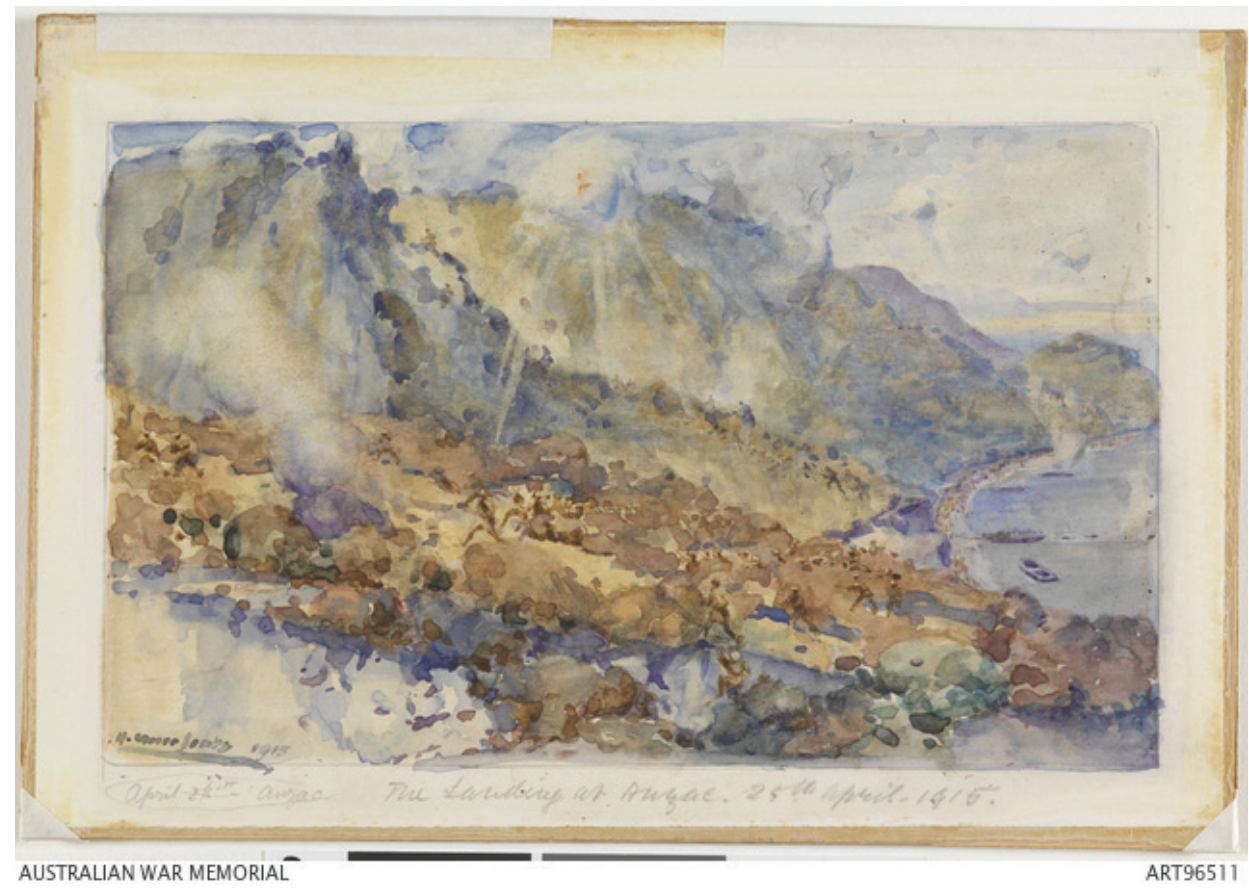

G. 4: Horace Millichamp Moore-Jones, 25 Nisan 1915'te Anzak’te Karaya Çıkış, 1915, Kağıt üzerine suluboya, 17.4 x $25.6 \mathrm{~cm}$., Australian War Memorial, Campbell (https://www.awm.gov. $\mathrm{au} /$ collection/C2091420)

Sanatçının Anzak Koyu'nu çevreleyen tepelerin denizden görünümünü veren resminde Türklerin açtı̆̆ top ateşinin dumanları da görülmektedir (G. 3). Çıkarmanın kumluk bir bölge olan Arıburnu ve Seddülbahir'e yapılması planlanmış ancak çıkarma gemileri akıntıyla sürüklenince kumluk Kabatepe bölgesi yerine kayalık Arıburnu kesimine çıkmak zorunda kalmışlardır ${ }^{13}$. Karaya çıkış anını resimleyen Horace Jones'un yaptığı eskiz, Australian War Memorial'in belirttiğine göre Anzak çıkarmasının profesyonel bir sanatçı tarafından yapılmış bilinen en eski resmidir ${ }^{14}$ (G. 4). Resimde kıyıya çıkan askerler Türklerin açtığı ateşin altında koşarak tepelere doğru ilerlemektedirler. 


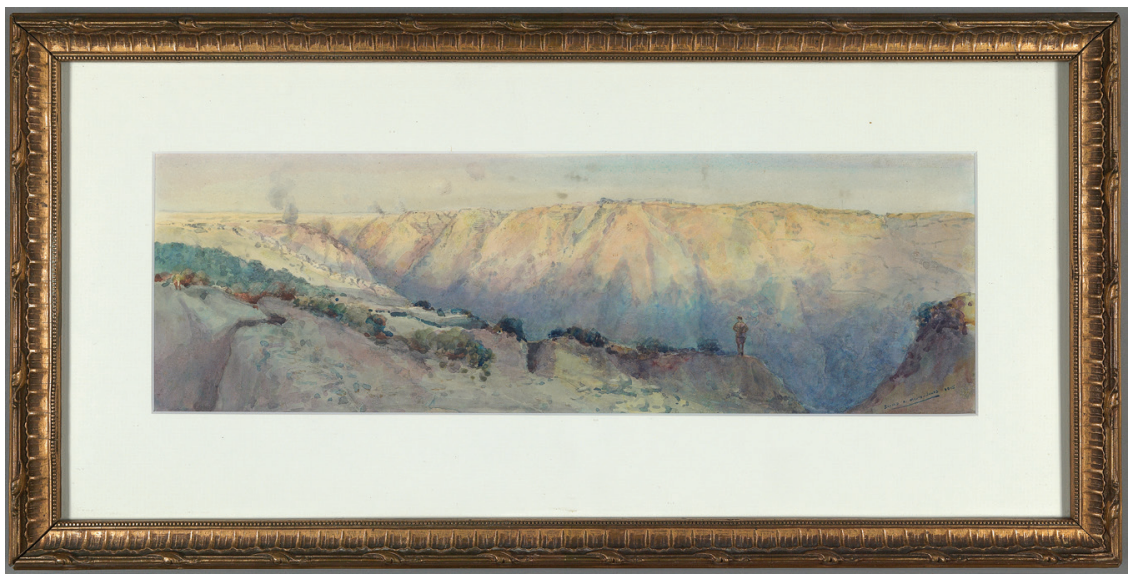

G. 5: Horace Millichamp Moore-Jones, Anzak Koyu'nun Tepelerinden Eskiz, 1915, Kağıt üzerine suluboya, 34x68 cm., Auckland Museum (https://www.aucklandmuseum.com/discover/ collections/explore-highlights/the-anzac-evacuation-of-gallipoli)

Sanatçının kıyıya çıktıktan sonra yaptığı resimlerde kayalık olan arazinin durumu daha yakından görülmektedir (G. 5). Çıkarma yapan askerler bu kayalık araziye çeşitli adlar vermişlerdir. Örneğin; 25 Nisan sabahı Anzak Koyu'nun kuzeyine çıkan askerler Arıburnu Yarları'nın tam ortasında bulunan denize doğru çıkıntı yapmıs olan kısmı, Mısır'da kamp yaptıkları sırada gördükleri sfenkse benzetmişler ve buraya "sfenks" adını takmışlardır ${ }^{15}$. Horace Jones'un bu adı taşıyan resminde sağ üst kısımda sfenkse benzeyen kaya, sağ alt köşede ise Anzak askerleri görülmektedir (G. 6). Nitekim Anzaklar sfenksin güneyindeki korunaklı alana "Wellington Terrace" ve "Reserve Gully" adını vermişler ve burası ihtiyat birliklerinin konaklama yeri olmuştur. Sfenksin kuzeyindeki dere ise yük katırlarının saklandığı yerdi ${ }^{16}$.

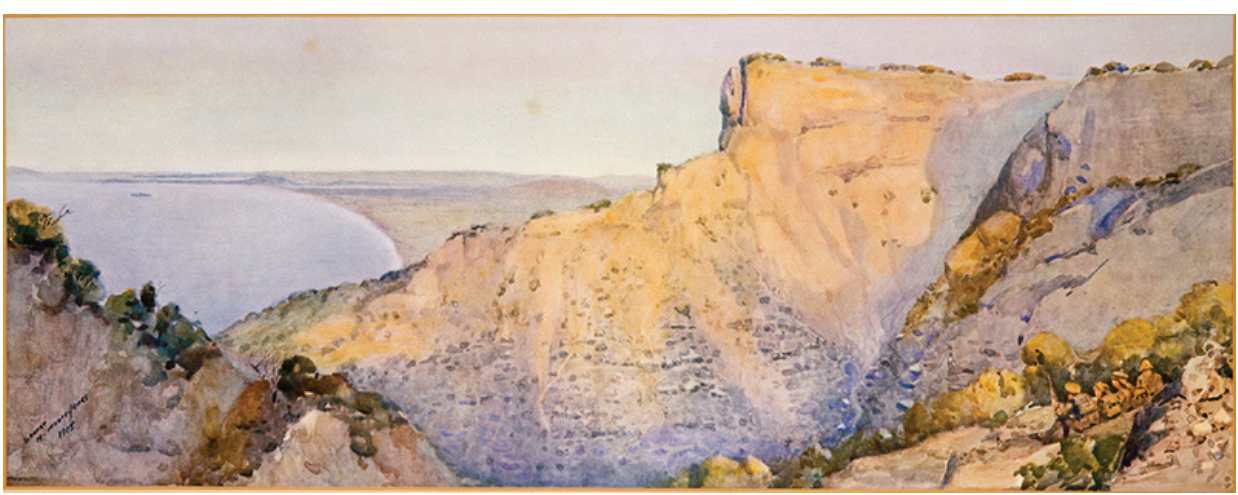

G. 6: Horace Millichamp Moore-Jones, Sfenks, 1915, Litograf, 21.6 x 56 cm., Özel Koleksiyon (https://archives.govt.nz/images/the-sphinx-gallipoli)

15 "Sfenks", Çanakkale Muharebeleri, erişim 24 Şubat 2020, https://canakkalemuharebeleri1915.com/genel/ muharebe-alani-yer-isimleri/ariburnu/265-sfenks-the-sphinx

16 "Wellington Terrace", Çanakkale Muharebeleri, erişim 24 Şubat 2020, https://canakkalemuharebeleri1915. $\mathrm{com} /$ genel/muharebe-alani-yer-isimleri/ariburnu/495-wellington-terasi-wellington-terrace 


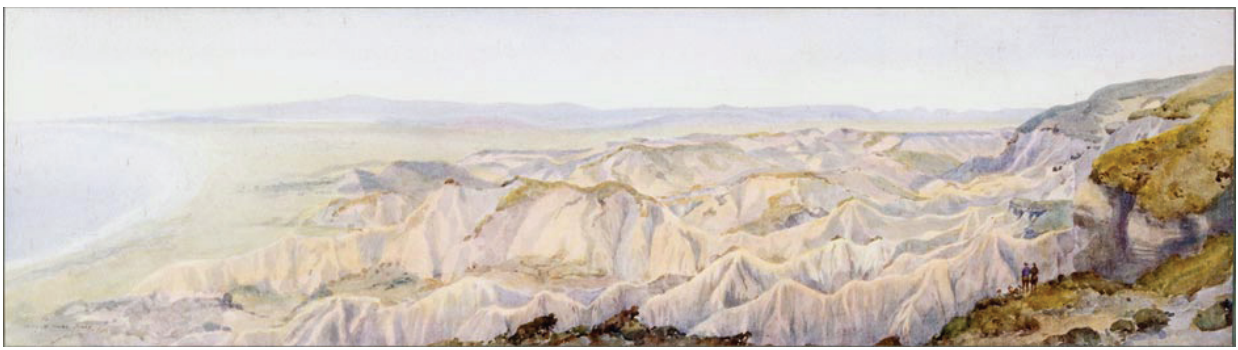

G. 7: Horace Millichamp Moore-Jones, Suvla’ya Doğru Ürkütücü Topraklar, 1915, Kağıt üzerine suluboya, $17.8 \times 69.8 \mathrm{~cm}$., Archives New Zealand (https://nzhistory.govt.nz/media/photo/moore-jones-painting-of-gallipoli)

Sanatçının çok kayalık bir bölge olan Suvla’nın görünüşünü yansıttığı bir resimde sağda ayakta duran iki asker figürü olasılıkla gözetleme yapan Osmanlı askerleri olmalıdır (G. 7) ${ }^{17}$. Jones, Türk siperlerinin pozisyonlarını da göstermiştir (G. 8). Aynı şekilde Anzakların pozisyonlarını da resimlemiştir (G. 9). Resmin merkezinde Fransız ve İngiliz birliklerinin ele geçirmeye çalıștıkları Achi Baba (Alçı Tepe) görülmektedir. Ressamın durduğu nokta ise Gaba Tepe'dir. (Kabatepe) ${ }^{18}$.

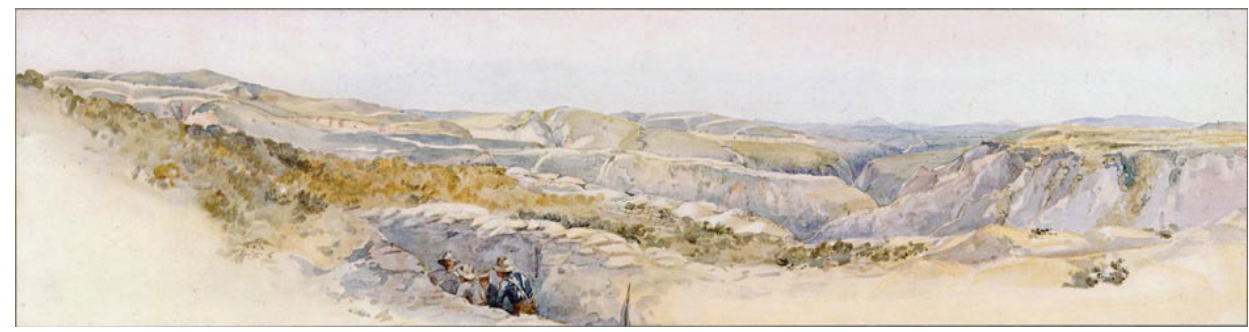

G. 8: Horace Millichamp Moore-Jones,Türk Siper Pozisyonlar1, 1915, Archives New Zealand (https://nzhistory.govt.nz/media/photo/moore-jones-painting-of-gallipoli)

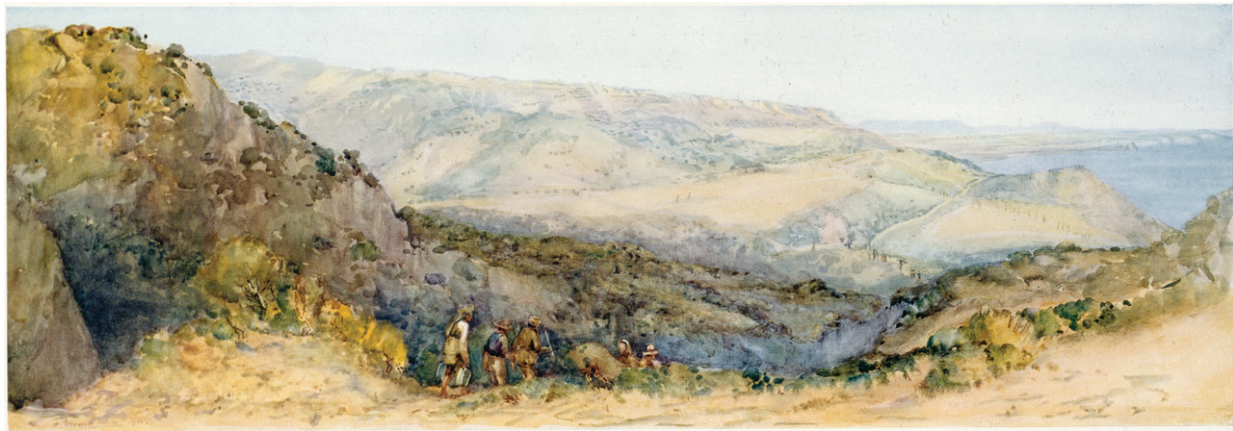

G. 9: Horace Millichamp Moore-Jones, Avustralyalıların Pozisyonu En Sağ Taraf, 1915, Kağıt üzerine suluboya, $20.5 \times 54 \mathrm{~cm}$., Archives New Zealand (https://archives.govt.nz/images/the-australian-positions-extreme-right-gallipoli)

17 "Moore-Jones' Gallipoli Landscapes", New Zealand History, erişim 5 Ağustos 2018, https://nzhistory.govt.nz/media/photo/moore-jones-painting-of-gallipoli

18 "Australian positions", Jonathan Grant Gallery, erişim 7 Haziran 2019, http://jgg.co.nz/artist/australian-positions-extreme-right/ 
Çanakkale Muharebesi sırasında İtilaf Devletleri üs olarak kullanmak için önce Mondros'u düşünseler de 27 Mayıs'ta Majestik zırhlısının torpillenerek batırılması ve donanmanın zorlanması sonucunda İmroz adasında (Gökçeada) karar kılmışlardır. General Hamilton önce çadırda kalmış ancak olumsuz koşullar yüzünden sonra taş bir kulübeye taşınmıştır ${ }^{19}$. Jones, generalin iki karargâhını da resimlemiştir. G. 10'da generalin ilk basit karargahı görülmektedir. Çadırın önünde duran askere solda duran diğer asker selam vermektedir. Karargâhın üstünde uçan iki uçak da resimde yer almaktadır. Generalin İmroz' daki ikinci karargâhını gösteren resimde ise sol tarafta generalin karargâhı olan kulübe, onun arkasında çadırlar bulunmaktadır (G. 11). Karargâhın yakınlarında bir zeplin hangarı ve sanatçının çalışı̆̆ğ Printing bölümünün yer aldığı bir başka resminden anlaşılmaktadır (G. 12).

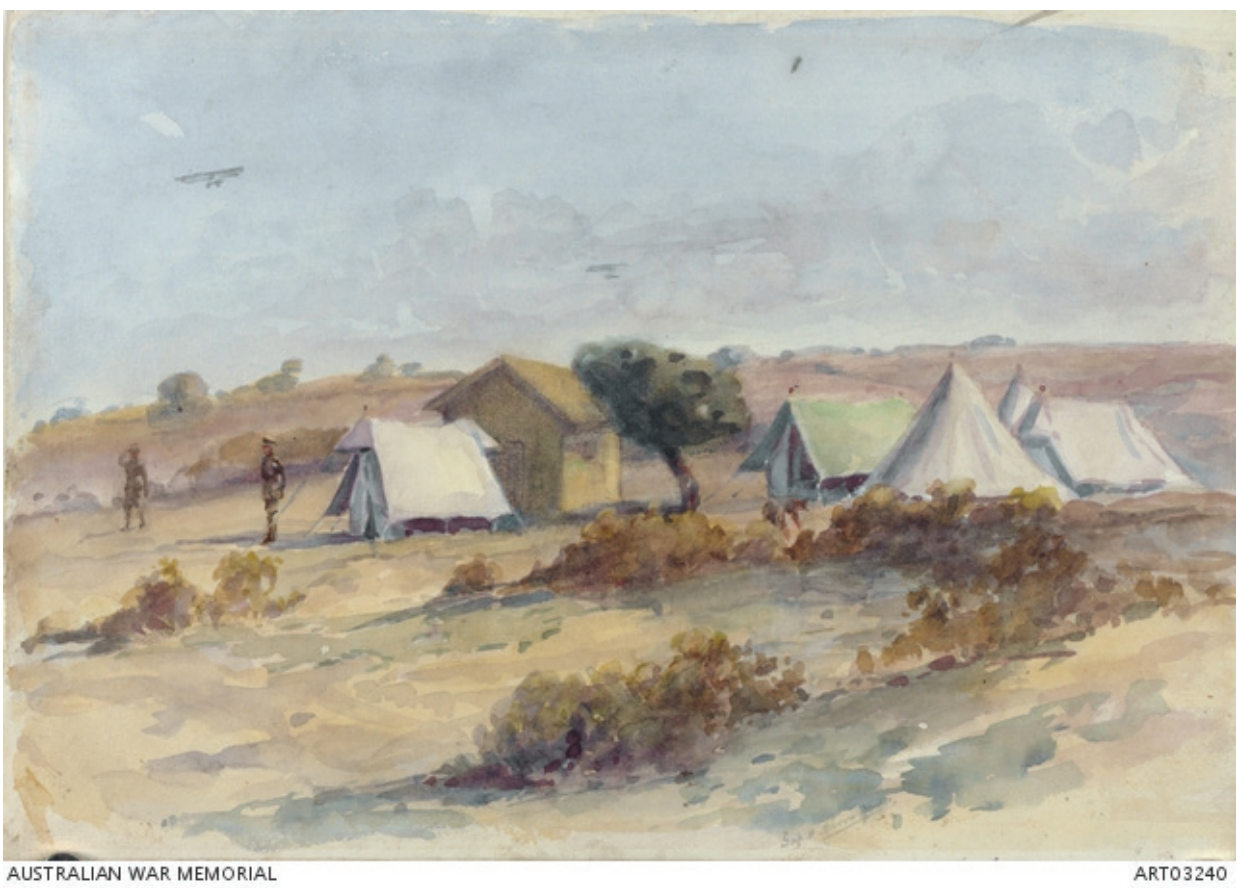

G. 10: Horace Millichamp Moore-Jones, General Sör Ian Hamilton'un Basit Çadırı, İmroz, 1915, Kağıt üzerine kalem ve suluboya, $17.9 \times 25.9 \mathrm{~cm}$., Australian War Memorial, Campbell (https://www.awm.gov.au/collection/C176842)

Anzaklar, top bataryalarını yerleştirdikleri düzlüğe ise Yarbay Arthur Plugge'ın adını vermişlerdir. Türk tarafı Asteğmen Muharrem komutasında 27. Piyade alayının seksen kişilik takımıyla burayı savunmaya çalışmışlar ancak komutan ve askerlerin çoğu şehit olunca Korku Deresi’ne çekilmişler ve bu düzlüğe Hain Tepe adını ver-

19 Çiğdem Şahin, "Çanakkale Savaşlarında İtilaf Kuvvetleri Üssü İmroz Adası (Gökçeada)", Savaş ve Toplum -Savaş Üzerine Yazılar, (Konya: Eğitim Yayınevi, 2016), 230-231 
mişlerdir ${ }^{20}$. Jones'un bu platoyu gösteren resminde akşam açılan ateşin dumanları görülmektedir (G. 12). Anzaklar ayrıca yeraltı sığınakları da yapmışlardır. Jones'un bunları gösteren bir resmi de vardır (G. 13). Yeraltı sığınaklarının yakınında bir bomba imal yeri olduğu da yine Jones'un bir eskizinden anlaşılmaktadır (G. 14). Resmin sol tarafinda bomba yapan bir asker yer almaktadır.

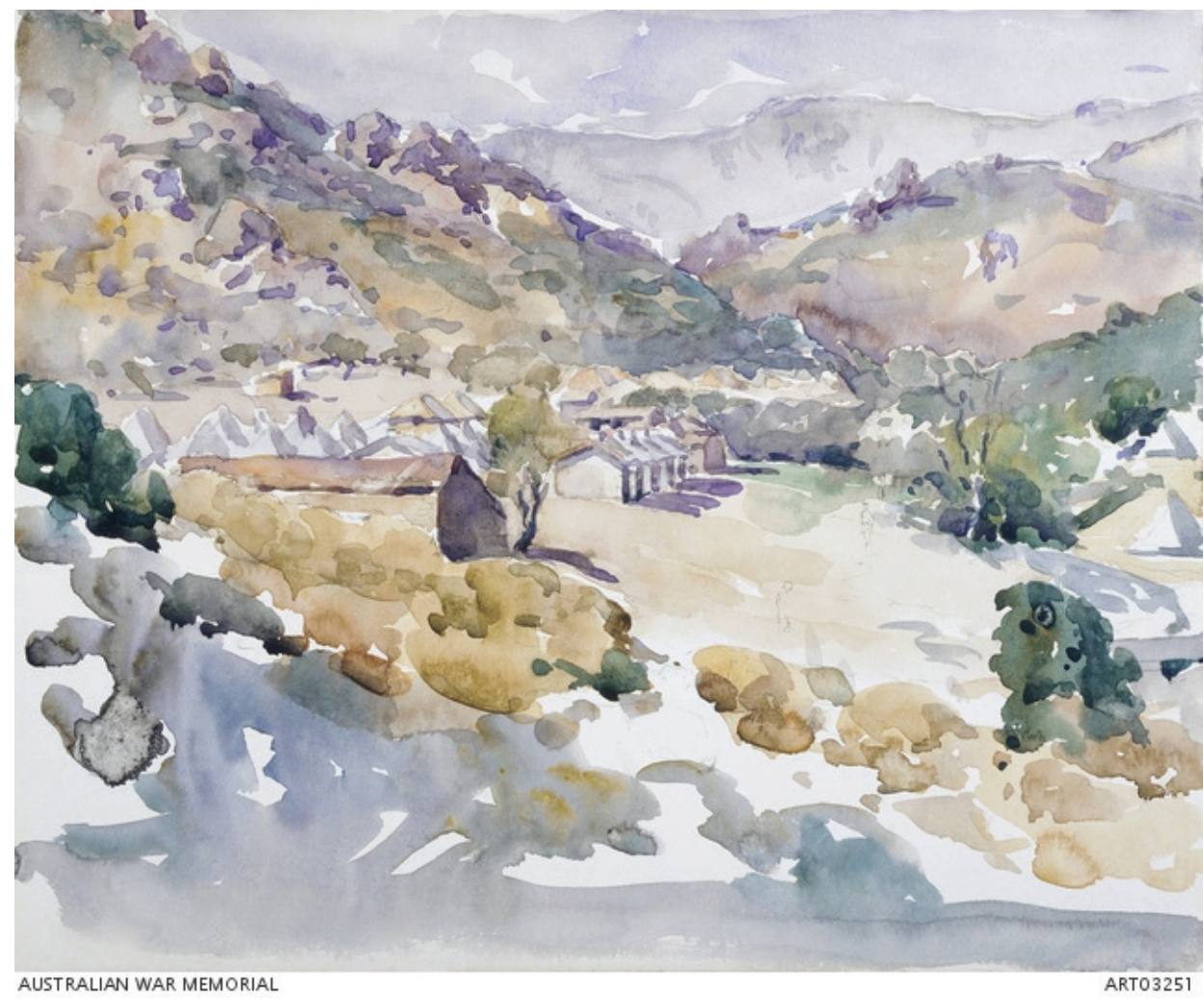

G. 11: Horace Millichamp Moore-Jones, Generalin Taş Kulübesi: Kış Karargahları, General Baş Karargahı, İmroz, 1915, Kağıt üzerine kalem ve suluboya, 21.3x $26.1 \mathrm{~cm}$., Australian War Memorial, Campbell (https://www.awm.gov.au/collection/C176856)

20 "Hain tepe ", Çanakkale Muharebeleri, erişim 27 Şubat 2020, https://canakkalemuharebeleri1915.com/genel/ muharebe-alani-yer-isimleri/ariburnu/198-hain-tepe-plugge-s-plateau 


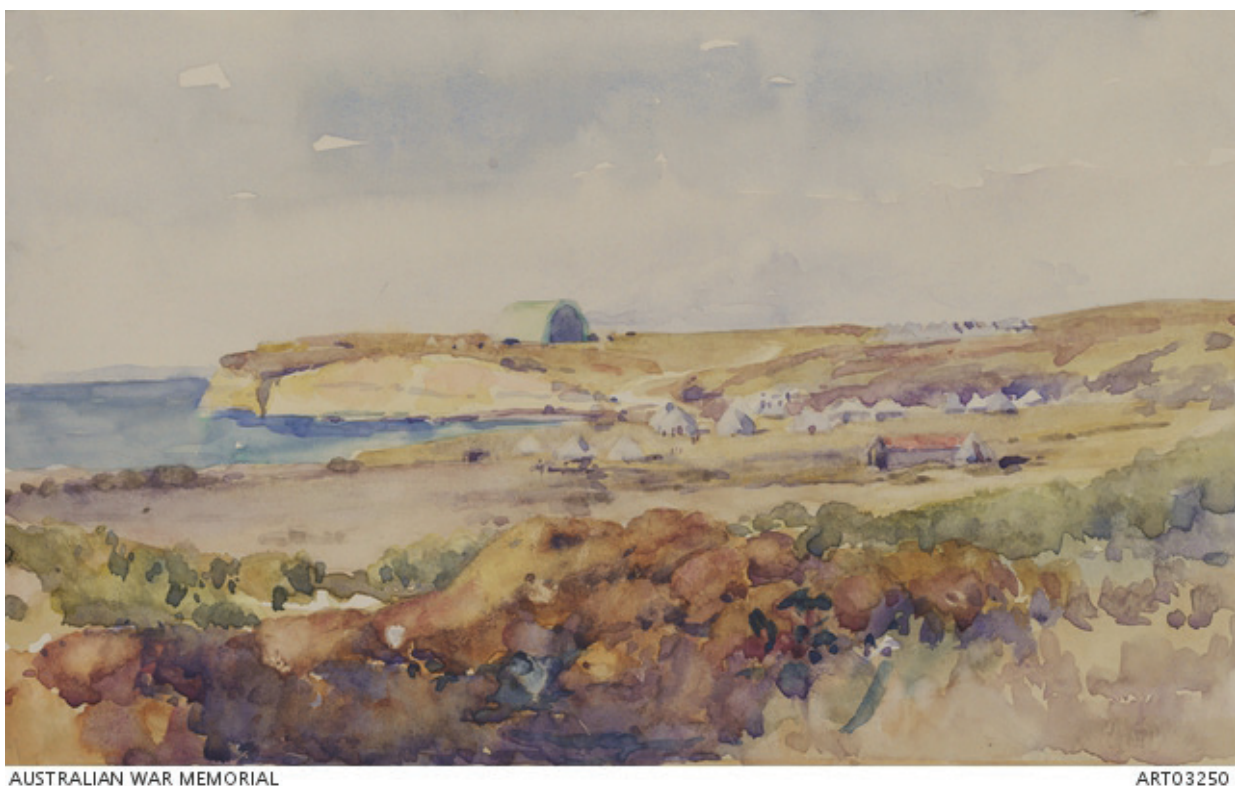

G. 12: Horace Millichamp Moore-Jones, Bask1 Bölümü, General Baş Karargahı Zeplin Hangarı, 1915, Kağıt üzerine kalem ve suluboya, 21.2x26.1 cm., Australian War Memorial, Campbell (https://www.awm.gov.au/collection/C172796)

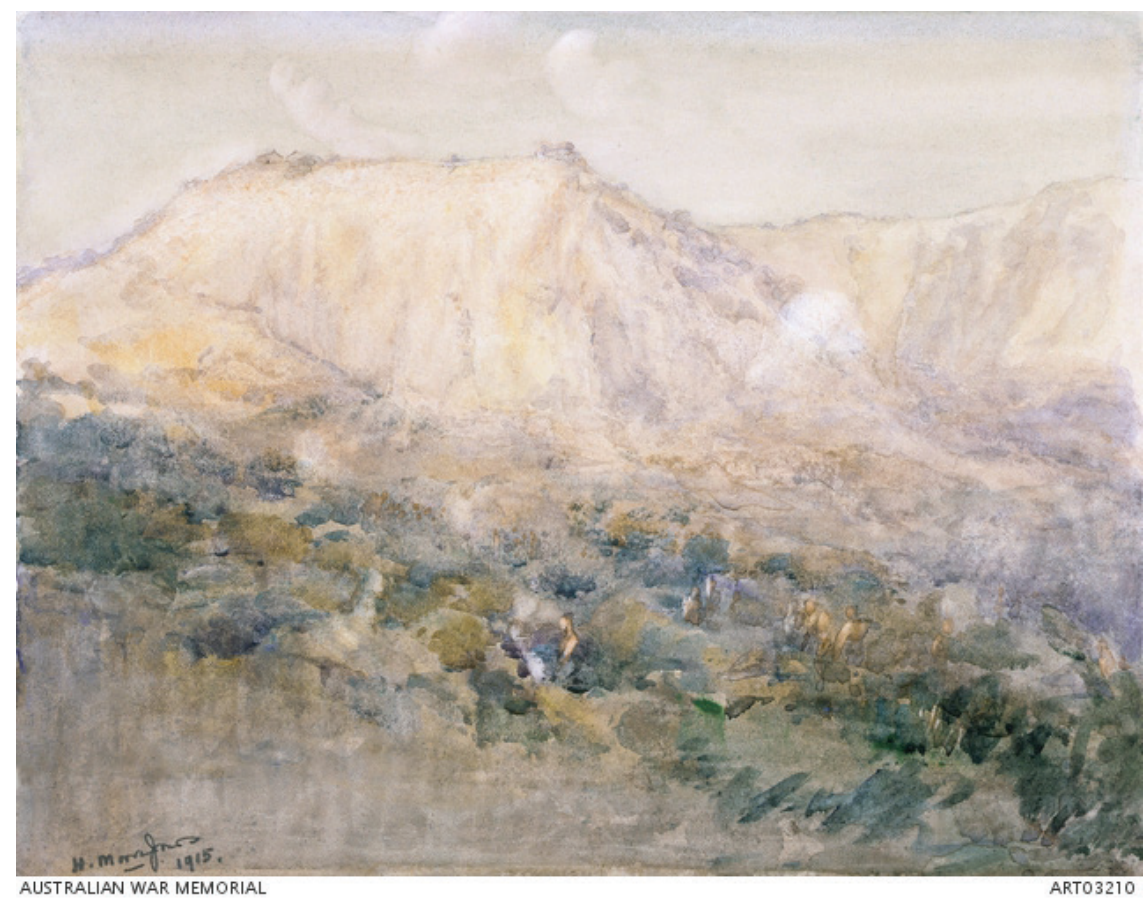

G. 13: Horace Millichamp Moore-Jones, Plugge'1n Platosu, Batıdan Görünüm Akşam, 1915, Kağıt üzerine kalem ve suluboya, $20.3 \times 26.0 \mathrm{~cm}$., Australian War Memorial, Campbell (https://www.awm.gov.au/collection/C172827) 


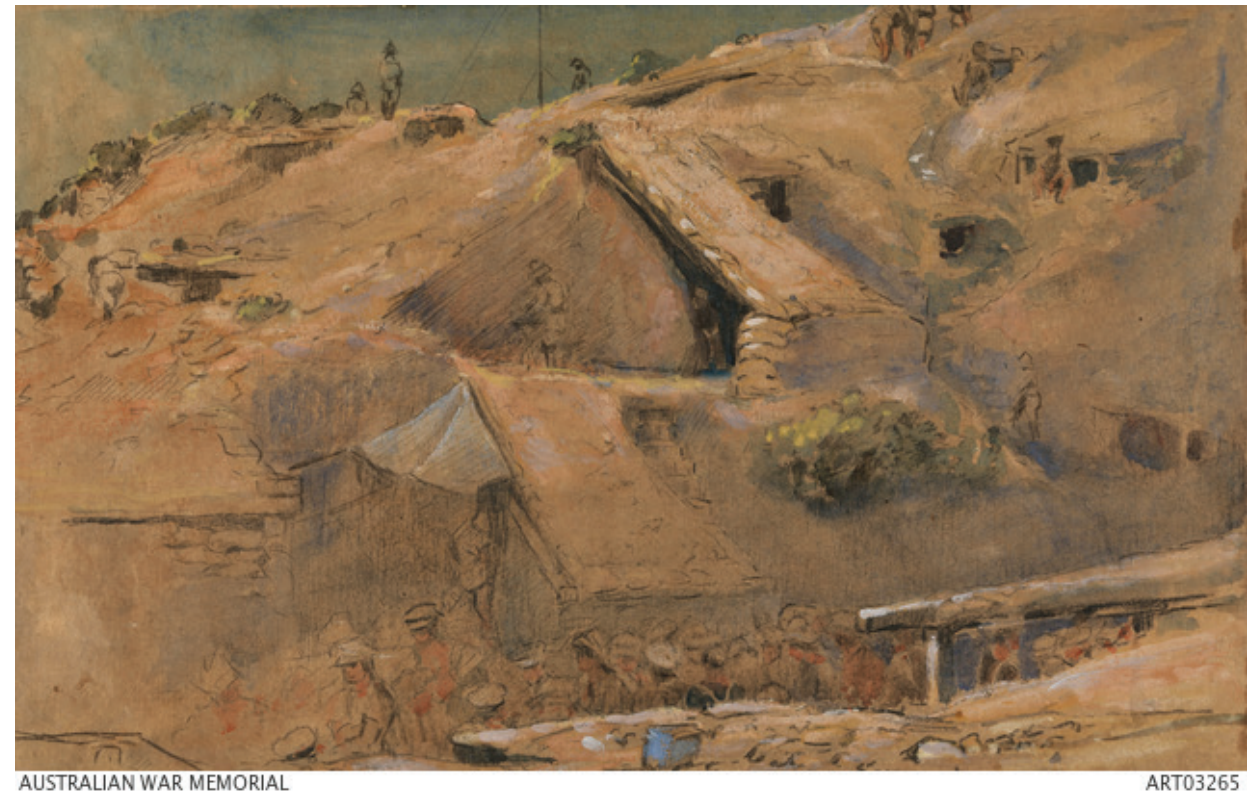

G. 14: Horace Millichamp Moore-Jones, General Birdwood'un Yeraltı Sığınağı, Anzak Yolu, Gelibolu, 1915, Kağıt üstüne suluboya, guaj, kalem, 22x34.3 cm., Australian War Memorial, Campbell (https://www.awm.gov.au/collection/C172830)

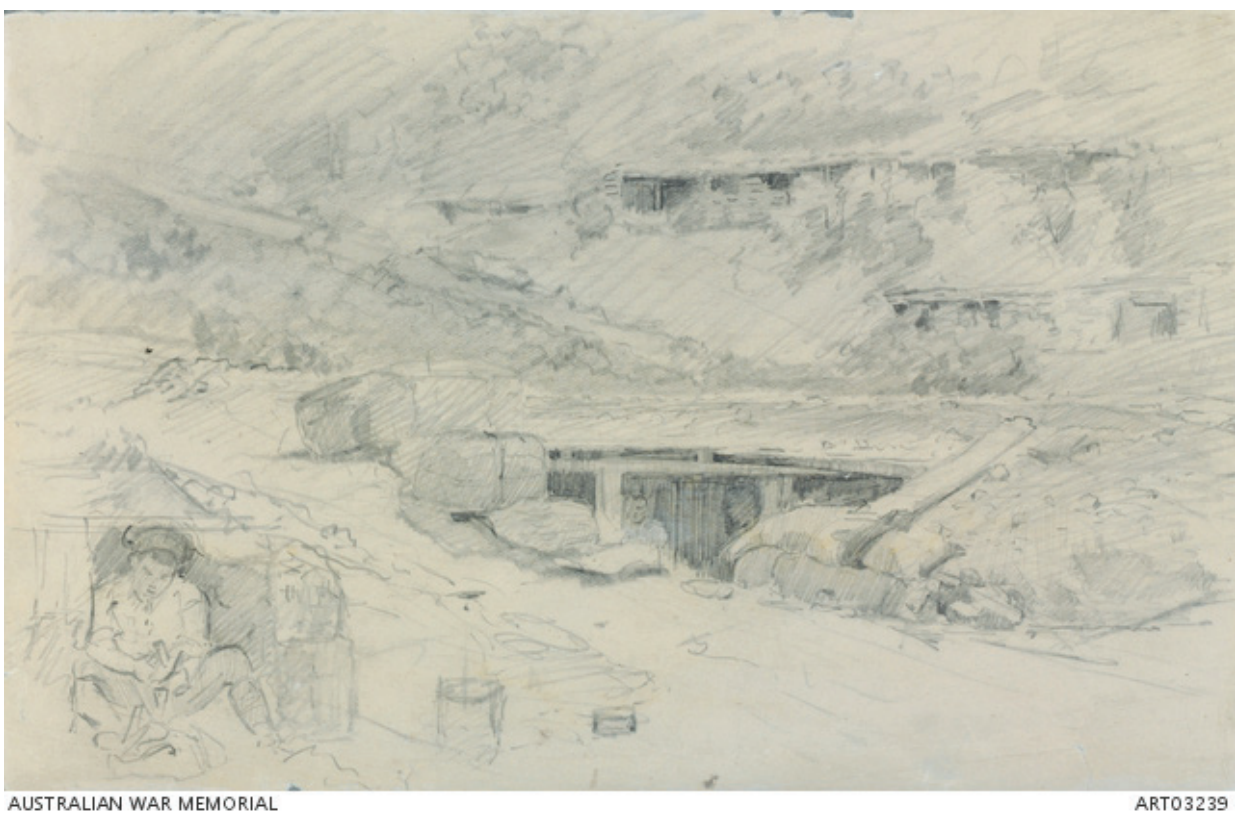

G. 15: Horace Millichamp Moore-Jones, Bomba Fabrikasının Girişi, Gelibolu, Kağıt üzerine karakalem, 13.8x21.5 cm., Australian War Memorial, Campbell (https://www.awm.gov.au/collection/C172790) 


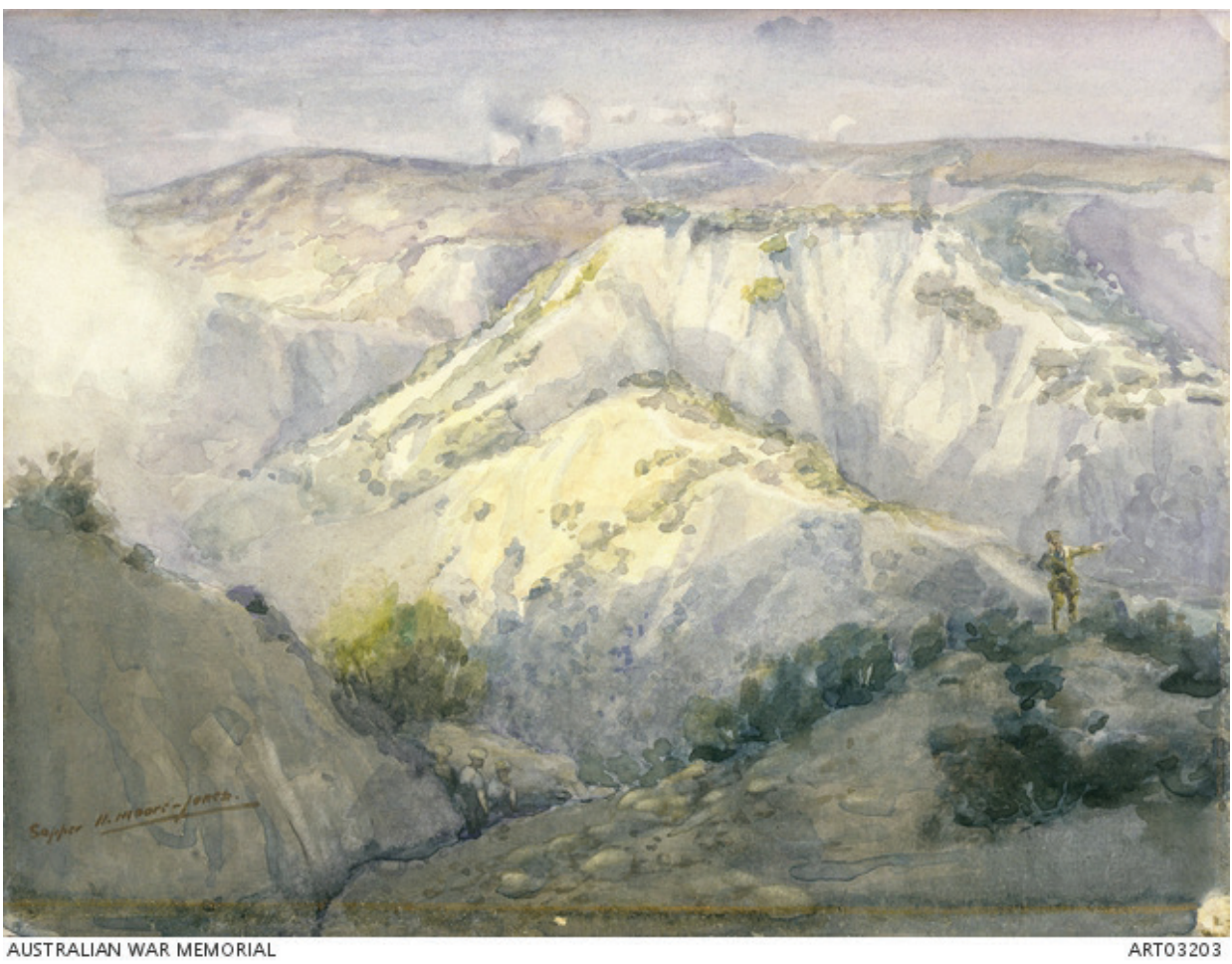

G. 16: Horace Millichamp Moore-Jones, Conk Bayırı ve 3 No.lu Karakolun Tepesi, Kağıt üzerine suluboya, 1915, 20.8x27.2 cm., Australian War Memorial, Campbell (https://www.awm.gov.au/collection/C167297)

8 Ağustos sabahı saat 03.30’da Anzak Birlikleri Conk Bayırı'na taarruz etmişıler ve bölgeyi ele geçirmişlerdir ${ }^{21}$. G. 16' da Conk Bayırı ve 3 No'lu Karakol'un tepesinden bir manzara görülür. Sağ tarafta eliyle sağı işaret eden bir asker, solda ise bir ağacin altında üç asker bulunmaktadır. Resmin üst bölümünde ve sol tarafında patlayan top mermilerinin dumanları görülmektedir.

8 Ağustos akşamında Albay Ali Rıza Bey komutasındaki 8. Tümen, Conkbayırı'na gelerek düşmana taarruz etmiş ancak başarılı olamamışlardır. 9 Ağustos’ta Kocaçimen-Besimtepe-Conkbayırı hattı Türk birliklerinin eline geçmiştir. Fakat düşman Conkbayırı'nın denize yönelik kesimindeki siperleri elinde tutmaktadır. ${ }^{22}$. Anafartalar Grubu Komutanı Mustafa Kemal, 10 Ağustos sabahı 23. Alay ve 24. Alay ile düşmana karşı taarruza geçme emri vermiştir. Çanakkale'deki en şiddetli süngü muharebesinin sonucunda düşman ağır kayıplar vermiş ve bölge Türklerin kontrolüne geçmştiri ${ }^{23}$. Türk ordusunun savunması ile kazanılan I. ve II. Anafartalar Zaferleri ile İtilaf dev-

21 Muzaffer Albayrak, 10 Ağustos 1915 Conkbayırı Süngü Hücumu (Ankara: Kültür ve Turizm Bakanlığ Yayınlar1, 2016), 54.

22 Albayrak, 10 Ağustos 1915 Conkbayırı Süngü Hüсumu, 56-57.

23 Albayrak, 10 Ağustos 1915 Conkbayırl Süngü Hücumu, 66, 68. 
letleri 19-20 Aralık gecesi Anafartalar ve Arıburnu cephesinden, 8-9 Ocak 1916'da da Seddülbahir'den çekilmişlerdir ${ }^{24}$.

Anzak ressam Horace Millichamp Moore-Jones'un resimleri Çanakkale Savaşı'nın âdeta günlüğü gibidir. Eskiz ya da suluboya tekniğindeki bu resimler, Batı'da eski bir geleneği olan savaş ressamlığının örneği durumundadır. Estetik bir kaygıdan çok, pratik amaçlara hizmet eden resimlerin topoğrafik özelliklerin verildiği, düşman menzillerinin gösterildiği bir tür casusluk niteliği taşıdıkları gözlenir. Bu resimlerde psikolojik herhangi bir ögeye rastlanmaz. Sanatçı, savaş sırasındaki duygularını belirtecek ya da izleyicide duygu uyandıracak herhangi bir ayrıntıya yer vermemiştir.

\section{Frank Rossiter Crozier}

Anzak askerlerin Gelibolu'daki psikolojik durumları, Frank Rossiter Crozier'in illüstrasyonlarında betimlenmiştir. Sanatçı, Avustralya'da Maryborough, Victoria'da doğmuştur. 18 yaşında okuldan ayrıldıktan sonra kısa bir süre kiliselerin iç dekorasyonunu yapan bir İtalyan dekoratör için çalışmıştır. Sekiz yıl boyunca bir bankada çalışmış, bir yandan da haftada üç akşam çizim derslerine katılmıştır. 1905'ten 1907'ye kadar Melbourne'daki National Gallery of Victoria Art School'da eğitim almış, 1907'de manzara ve çizim dallarında öğrencilere verilen ödülleri kazanmıştır. Savaş başlayınca Avustralya İmparatorluk Kuvvetleri'ne katılmış, 1915'te önce Mısır'a sonra Gelibolu'ya gönderilmiştir. 1916'da 1. Anzak Kolordusu Topoğrafik Bölümü ile çalışmak üzere Fransa'nın Marsilya kentine gitmiştir. 1917'de karargâhı Londra'da olan Australian War Records Section'a girerek kamuflaj eğitimi almıştır. 1918'de resmî savaş sanatçısı ve fahri teğmen olarak atanmıştır. Savaştan sonra 1919'da Avustralya'ya dönen sanatçının resmî savaş sanatçısı olarak görevi 1920'de sona ermiştir. 1936'da altı ay boyunca sanat danışmanı olarak Australian War Memorial'e atanmıştır. İkinci Dünya Savaşı sırasında Victoria, Maribyrnong'da bir mühimmat fabrikasında çalışmıştır ${ }^{25}$. Crozier'in üslubu gerçekçi ve izlenimci ögelerin birleşmesinden oluşmaktadır. Savaşa hümanist yaklaşımından ötürü övgüler alan sanatçı, ona rehberlik eden insani değerleri yansıtan çalışmalarıyla tanınmıştır ${ }^{26}$.

Gelibolu'da sedye taşıyıcısı olarak görev alan ressam, The Anzac Book diye adlandırılan 1916 yılında yayınlanan kitabın illüstrasyonlarından bazılarını yapmıştır. ${ }^{27}$ İllüstrasyonlardan biri "Babalarımız" adını taşır ve kitapta yer alan şiire eşlik etmektedir (G. 17). Bu resim, şiirde yer alan “...bilinmeyen topraklarl arayan gezgin ruhlar, babalarımız gibi korkusuz yiğit yürekler... "28 dizelerine uygun olarak İngiltere'nin parlak dönemlerinden biri olan Kraliçe Elizabeth (1533-1603) dönemi giysileri içindeki

24 Kurşun, "Çanakkale Muharebeleri", 207.

25 "Private Frank Rossiter Crozier", Australian War Memorial, erişim 15 Mayıs 2021, https://www.awm.gov. $\mathrm{au} /$ collection/P10676272

26 "Frank Crozier", Artists of the Great War, erişim 15 Mayıs 2021, https://artistsofthegreatwar.wordpress. com/2016/10/21/frank-crozier-c-1883-1948/

27 "Private Frank Rossiter Crozier".

28 Anonim, The Anzac Book, (London: The Cassel Company Ltd. , 1916), 15. 
şövalyeleri Anzak Koyu'nda göstermektedir. Bu resim aynı zamanda Anzak askerlerinin işgal ettikleri Türk topraklarında kendilerini nasıl gördüklerini de yansıtmaktadır.

Kahramanlık duyguları dışında Anzakların bu savaşta yer almalarının dinsel bir boyutu da vardır. Kitaptaki "Non Nobis” adlı şiirin adı, Zebur'un Vulgate çevirisindeki “...Non nobis Domine, non nobis sed nomini tuo da gloriam... "29 (Bizi değil Tanrım, bizi değil kendi adını şereflendir) şeklinde Tapınak Şövalyelerinin slogan $1^{30}$ da olan sözcükleri anımsatmaktadır. Crozier' in yaptı̆̆ı resimde Hristiyanlığın simgesi olan çam ağaçlarından biri yerde yüzükoyun yatan bir adamın üzerine devrilmiştir (G. 18). Ancak kitaptaki illüstrasyonda adamın bulunduğu bölüm bir yazı kartuşuyla kapatılmış, içine de "...Kalıntılarından daha büyük bir gurur -bu gözlerin görmesi için değil- bir gün vadiyi örtebilir. Bizi değil Tanrım...” yazılmıştır ${ }^{31}$. Büyük olasılıkla ağacın altında kalan adam imgesi hoş bulunmamış ve o bölümün kapanması uygun görülmüştür.

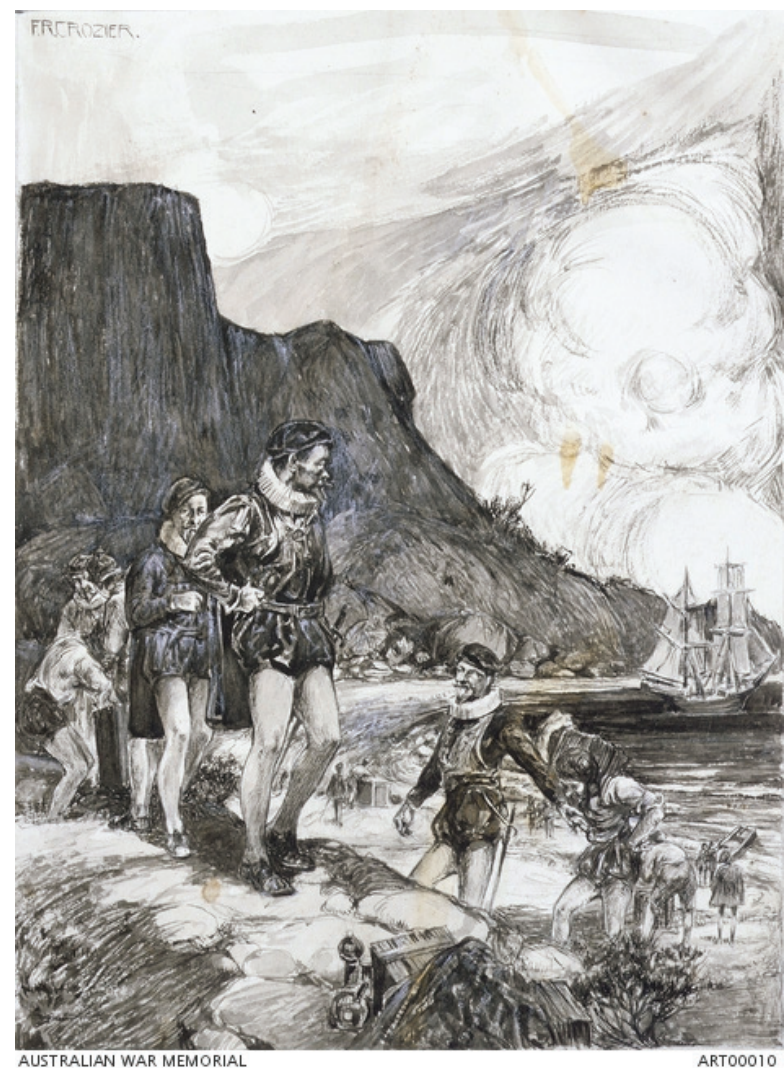

G. 17: Frank Crozier-William Keith Eltham, Babalarımız, 1915, Kağıt üzerine kalem ve mürekkep, 1915, 31.4x24.2 cm., Australian War Memorial, Campbell (https://www.awm.gov.au/collection/C169091)

29 Psalm 115:1

30 "Non Nobis Domine, Non Nobis, Sed Nomini Tuo Da Gloriam", Templars Today, erişim 11 Şubat 2020, https://www.templarstoday.org/2019/03/09/non-nobis-domine-non-nobis-sed-nomini-tuo-da-gloriam/

31 Anonim, The Anzac Book, 11. 


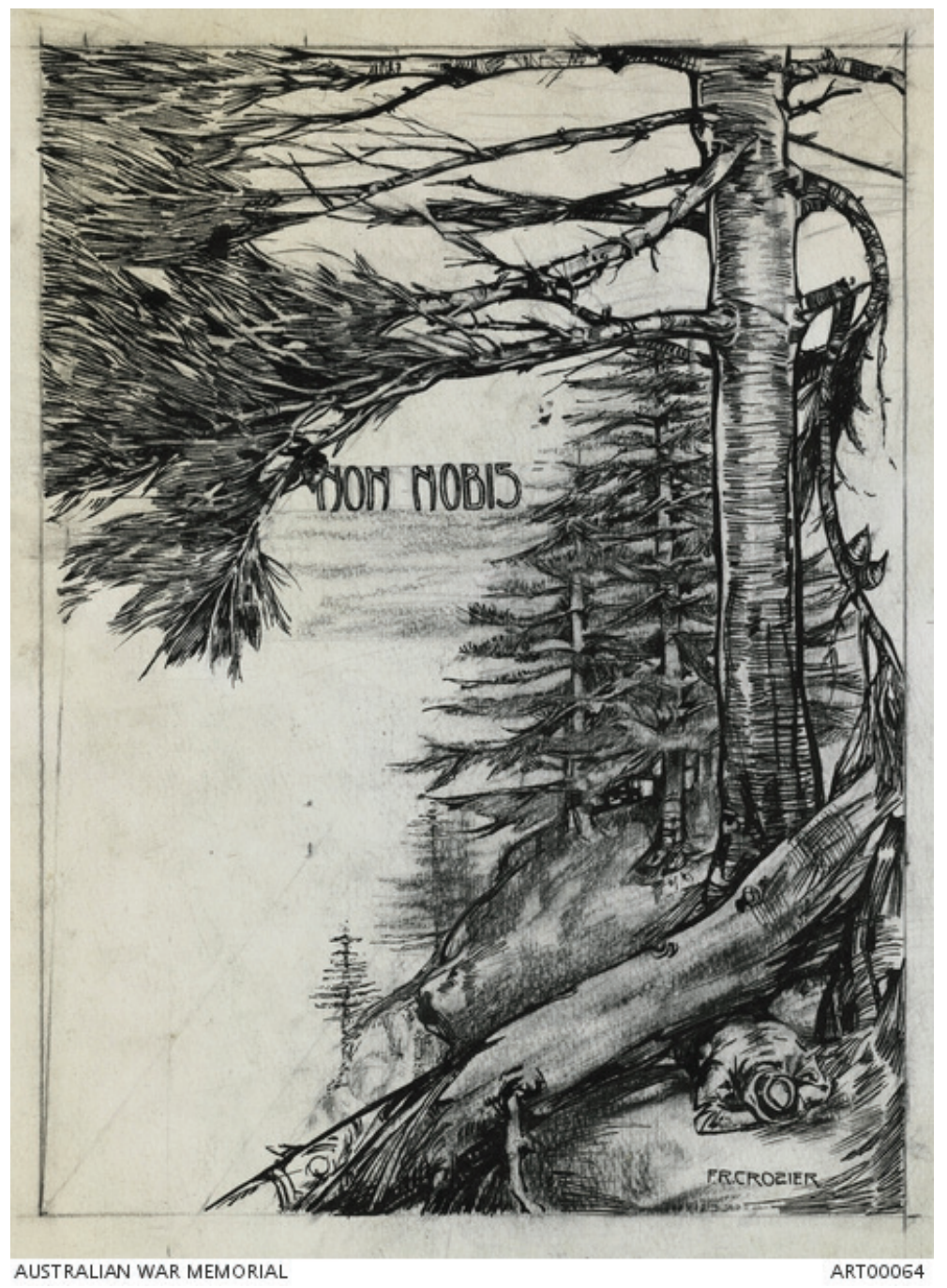

G. 18: Frank Crozier, Non Nobis, 1915, Kağıt üzerine kalem ve mürekkep, $36.2 \times 27 \mathrm{~cm}$,, Australian War Memorial, Campbell (https://www.awm.gov.au/collection/C169082) 


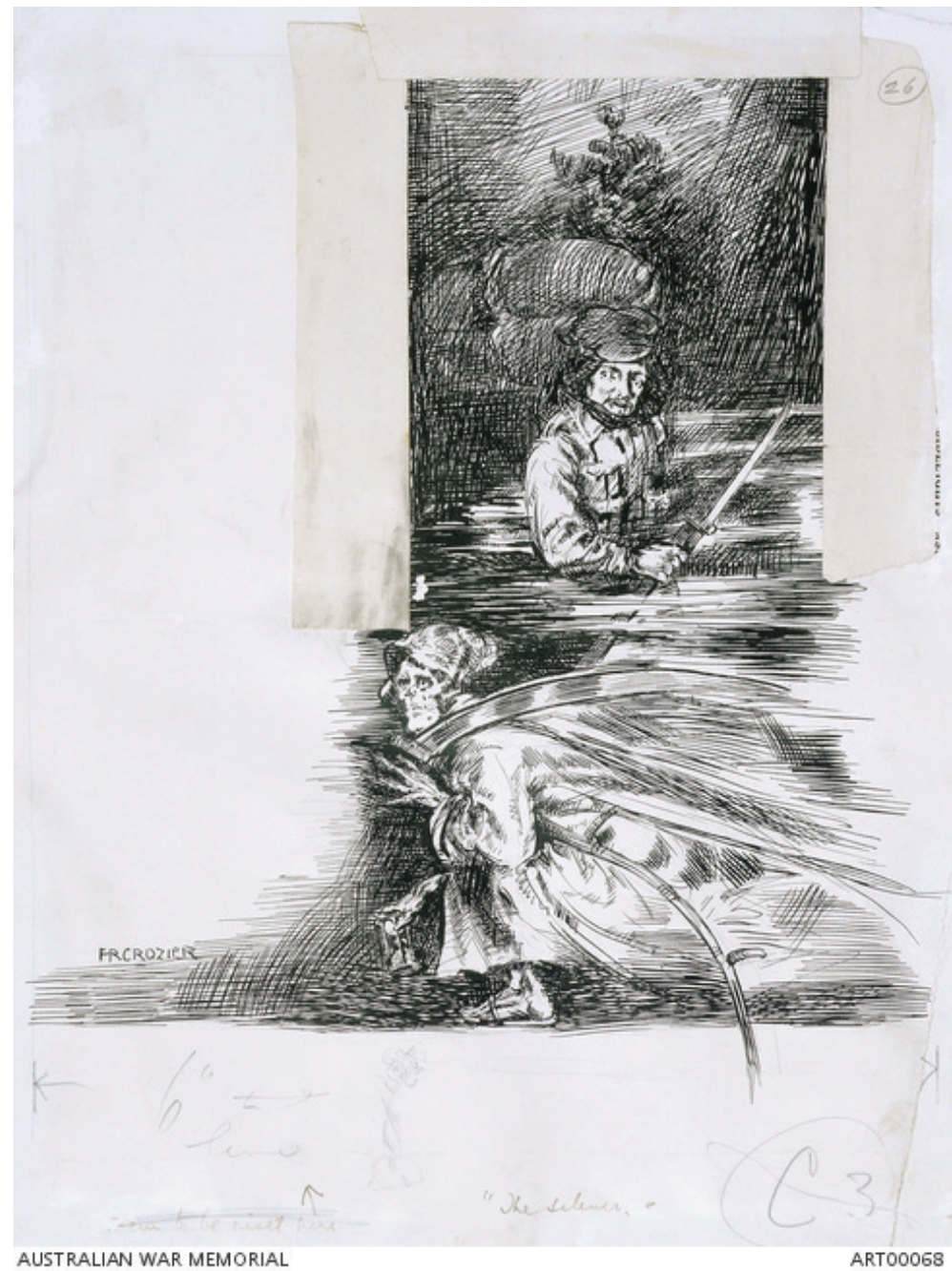

G. 19: Frank Crozier, Sessizlik, 1915, Kağıt üzerine kalem ve mürekkep, $32.1 \times 25.4 \mathrm{~cm}$., Australian War Memorial, Campbell (https://www.awm.gov.au/collection/C169081) 


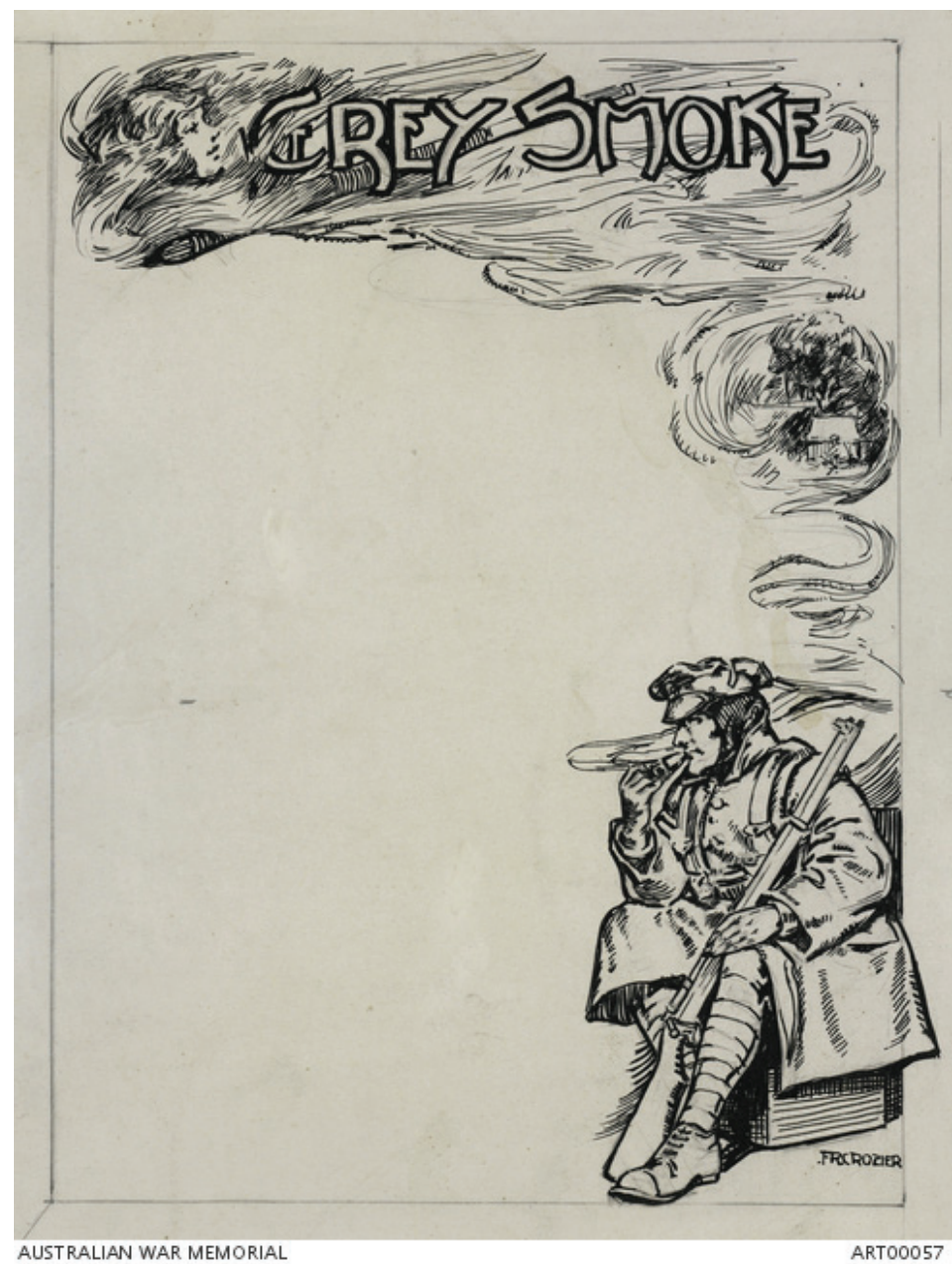

G. 20: Frank Crozier, Gri Duman, 1915, Kağıt üzerine kalem ve mürekkep, 31.7x25 cm., Australian War Memorial, Campbell (https://www.awm.gov.au/collection/C169090)

Ancak zaman ilerledikçe Anzakların kahramanlık duyguları yerini korkuya bırakmıştır. "Sessizlik" adlı şiirde uykusuz askerlerin ölüm etraflarında kol gezerken nöbet yerlerinde bir hortlak gibi dikildikleri ve "sessizliğe ne olacak" diye sordukları görülmektedir ${ }^{32}$. Crozier'in resmi de bu şiiri birebir anlatır. Elinde süngüsüyle nöbet tutan bir asker korkuyla açılmış gözleriyle elinde taşıdığı tırpanıyla önünden geçen ölüm figürüne bakmaktadır (G. 19).

Sanatçının "Gri Duman" adlı resmi, elinde tüfeğiyle yere oturmuş bir askerin piposunun dumanında özlediği evini ve sevgilisini göstermektedir (G. 20). Horace Jones'un resimleriyle savaşın günlüğünü tutması gibi Crozier'in resimleri de savaşçıların günden güne değişen ruhsal durumlarını yansıtmaktadır. 


\section{George Washington Thomas Lambert}

Çanakkale'ye savaşmaya gelen bu iki Anzak ressamın dışında yenilgiden sonra 1919'da özel izinle buraya gelip savaş sahneleri ve portreler betimleyen resmî savaş ressamı George Washington Thomas Lambert'in resimleri ise yenilgiyle sonuçlanan savaşın ardından Anzakların konuya bakışını göstermesi açısından ilginçtir. Sanatçı, demiryolu mühendisi olan babasının vazifesi dolayısıyla Rusya'da St. Petersburg'da doğmuştur. Babası ölünce annesi ve yine demiryolu mühendisi olan dedesiyle önce Almanya'ya sonra da Avusturalya'ya yerleşmişlerdir. 1899'da Wynne Ödülü'nü kazanan sanatçı bir y1l Sidney'de Julian Ashton Art School'da çalıştıktan sonra hükümet bursuyla Paris ve Londra'ya gitmiştir. 1917'de Avustralya'nın resmî savaş ressamı olmuştur ${ }^{33}$.

Lambert'e Gelibolu gezisi sırasında bir Türk subayı eşlik etmiş ve onu bilgilendirmiştir. Sanatçı, Binbaşı Zeki Bey adlı bu subayın da karakalem bir portresini yapmıştır (G. 21). Anzak işgali sırasında Gelibolu'da bulunan bu subay, savaşla ilgili ressama ilk elden bilgi verebilecek kişidir ${ }^{34}$. Lambert onu profilden göstermeyi yeğlemiştir. Portrede başında kalpağı ve üzerinde üniforması olduğu görülmektedir.

Sanatç1, 25 Nisan 1915'te Gelibolu'ya çıkartma yapan Anzakları Kabatepe'de betimlemiştir (G. 22). Savaşa bizzat katılan Moore-Jones'un aksine hayalinde tasarlayarak yaptığı bu resimde Avustralya Birliklerinin kayalık tepelere (Kabatepe) tırmandığ 1 anı göstermiştir. Kayalık araziye tırmanan askerler zorlukla fark edilmektedir. Askerlerin bir kısmı yere düşmüş veya ölü olarak gösterilmiştir. Tepelerin üstünde Türklerin açtığı top ateşinin dumanı da bu ölümlerin nedeni hakkında ipucu vermektedir.

33 "Lambert, George Washington", Australian Dictionary of Biography, erişim 1 Nisan 2020, http://adb.anu.edu.au/biography/lambert-george-washington-7014

34 "Major Zeki Bey", Australian War Memorial, erişim 14 Mart 2021, https://www.awm.gov.au/collection/ ART02868 


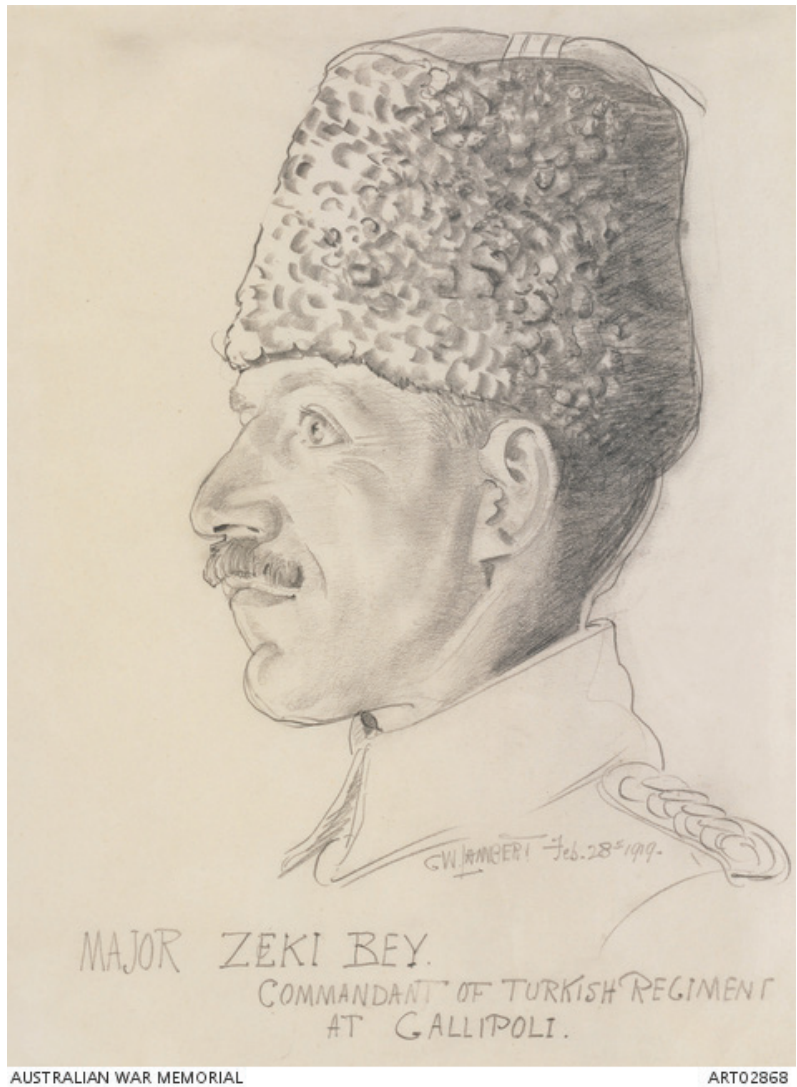

G. 21: George Lambert, Binbaşı Zeki Bey, 1919, Kağıt üzerine karakalem, 30.6x23.3 cm., Australian War Memorial, Campbell (https://www.awm.gov.au/collection/C176443)

Lambert'in resimlemeyi seçtiği bir başka önemli savaş anı, 3. Hafif Süvari Birliği'nin Nek’teki (Boyun) hücumudur (G. 23). Burası Anzak cephesinin kuzey ucunda önemli bir mevziydi. 7 Ağustos 1915'te şafak vakti Avustralyalılar burada Türkler'in açtığı bir ateş seliyle karşılaşmış ve saldırıya katılan her beş kişiden dördü yaralanmış veya öldürülmüştür ${ }^{35}$. Resimde kayalık arazide ilerlemeye çalışan Anzak askerlerinin bazıları vurulup yere düşmüş, bazıları da düşmek üzereyken gösterilmiştir. Ressam, onları sağ tarafta yere diz çökmüş biri hariç arkadan veya yandan göstermeyi yeğleyerek yüzlerinin görülmesini önlemiş, böylece izleyicinin zor durumdaki askerlere sempati duymasının da önüne geçmiştir. Lambert'in savaşa katılmamasına karşıllk, savaş karşısında belgeci bir tutumu olduğu söylenebilir. Bölgeyi gezerek bilgi almış ve sonra hayalinde canlandırarak Anzaklar'ın yenildiği anları resimlemeyi seçmiştir. Bunu yaparken de duygusallığa yer vermemiş, gerçekçi bir üslup kullanmıştır. 


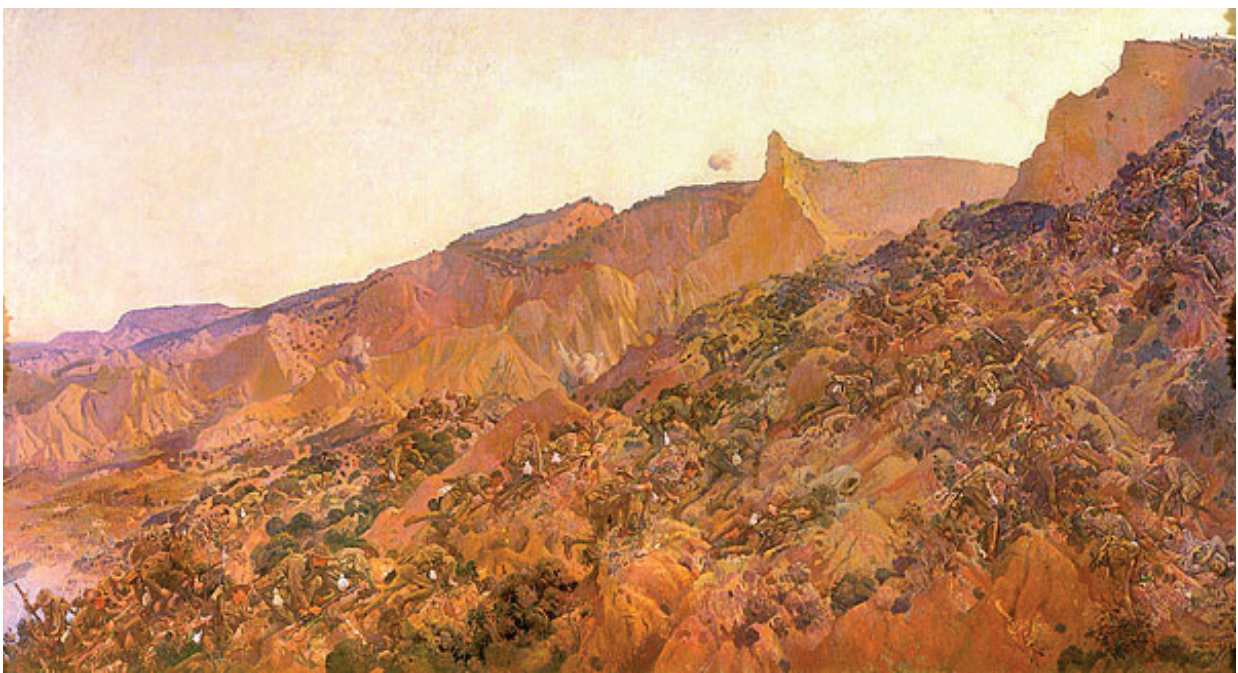

G. 22: George Lambert, Anzak Çıkartması 1915, 1920-2, Tuval üzerine yağlıboya, 190.5x350.5 cm., Australian War Memorial, Campbell (https://www.awm.gov.au/collection/C172139)

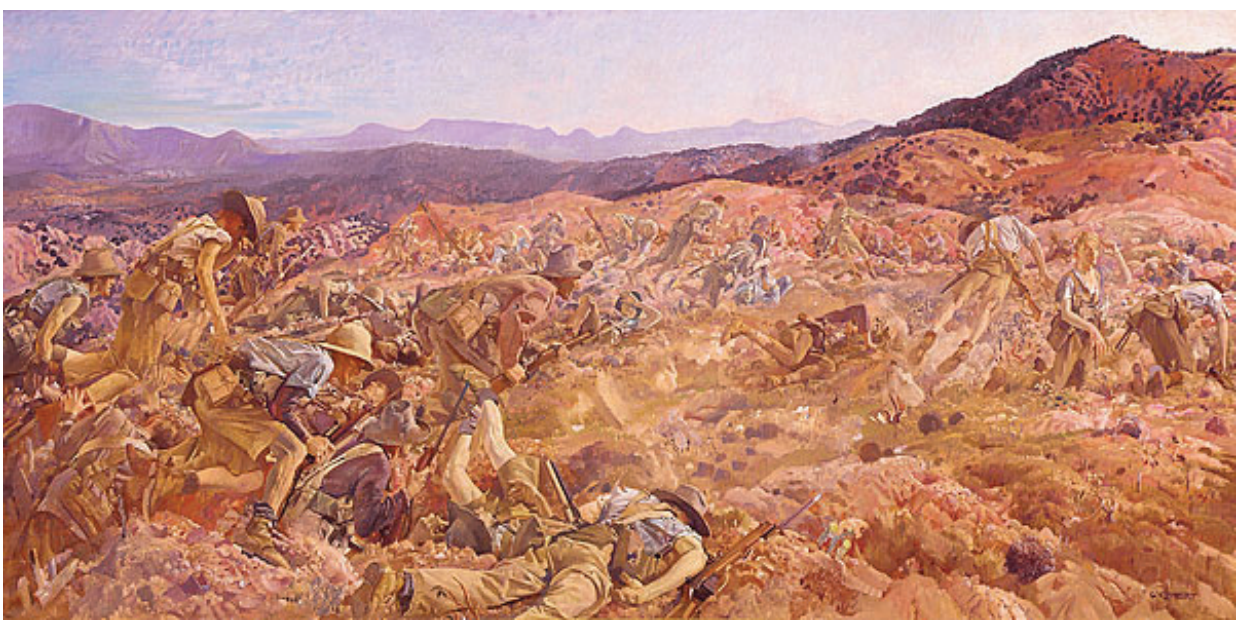

G. 23: George Lambert, Nek’teki 3. Hafif Süvari Birliği'nin Hücumu 7 Ağustos 1915, 1924, Tuval üzerine yağlıboya, $152.5 \times 305.7 \mathrm{~cm}$., Australian War Memorial, Campbell (https://www.awm.gov.au/collection/C172140)

Çanakkale'de yaşanan zorlu savaş ve alınan yenilgiye karşılık, Anzakların bu savaştaki varlığgı, Avustralya'nın “ulus” olması yolunda attığı bir adımdır. Dolayısıyla yenilmiş olmalarına rağmen bu savaşı betimlemek için Çanakkale'ye resmî bir savaş ressamı yollamaları şaşırtıcı bir durum değildir. Çünkü Anzakların bu savaşta yer almaları, bir sömürge ülkesi konumunda olan Avustralya'nın adının tüm dünyada duyulmasını sağlamış ve bu savaş sayesinde dünya sahnesinde varlıklarını kanıtlamışlardır. 


\section{Sonuç}

Çanakkale Savaşı'nı betimleyen üç Anzak ressamın da farklı tutumları olduğu görülmektedir. Büyük bir istekle yaşını küçük gösterip savaşa katılan Horace Millichamp Moore-Jones, resimlerinde savaşın âdeta bir günlüğünü tutmuştur. Onun resimlerine bakarken savaşın nasıl cereyan ettiğine ilişkin fikir sahibi olunmaktadır. Cepheleri ve orduların mevzilerini gösteren bu resimler sanatsal değil, askerî amaçla yapılmıştır. Düşman mevzileri hakkında bilgi vermek için büyük olasılıkla keşiflere çıkıp gizlenerek ya da dürbünle uzaktan bakılarak yapılmış bu resimlerde aynı zamanda bir tür askerî casusluk amacı güdülmüştür. Dolayısıyla resimlerde psikolojik boyuta yer verilmediği görülmektedir. Oysa Frank Rossiter Crozier'in The Anzac Book için yaptığı illüstrasyonlar, kahramanlık duygularıyla katılınan bu savaşın zaman geçtikçe Anzak askerler üzerindeki psikolojik etkilerini yansıtmaktadır. Kolayca kazanılacağını sandıkları bu savaşta askerler gittikçe umutsuzluğa kapılmaya, vatanlarının ve geride bıraktıkları kişilerin özlemi ağır basmaya başlamış ve savaşın ürkütücü yüzünü fark etmişılerdir. Duygusal bir bakış açısını yansıtan Crozier’nin resimleri askerlerin psikolojisini tüm gerçekliğiyle vermektedir. 1918'de sonlanan Birinci Dünya Savaşı'nın ardından 1919'da özel izinle Çanakkale'ye gelip araştırmalarda bulunduktan sonra büyük tuval resimleri yapan resmî savaş ressamı George Washington Thomas Lambert'in resimleri ise Anzak işgalinin ülkesi için ağır sonuçlarını yansıtmaktadır. Ancak Lambert bu resimlerde savaşın psikolojik boyutuna yine de yer vermemiş ve savaşı belgelemekle yetinmiştir. Yenilgilerine karşılık Avustralyalıların Çanakkale'ye bir savaş ressamı yollayarak bunu belgelemek istemeleri şaşırtıcı bulunabilir. Ancak bu savaş, Avustralyalıların dünya sahnesinde var olmalarını sağladığı ve ulus olma yolunu onlara açtığı için çok önemli bir dönüm noktası olmuştur. Dolayısıyla resmî savaş ressamlarını gönderip bu resimleri ısmarlamaları şaşırtıcı değildir.

Hakem Değerlendirmesi: Dış bağımsız.

Çıkar Çatışması: Yazar çıkar çatışması bildirmemiştir.

Finansal Destek: Yazar bu çalışma için finansal destek almamıştır.

Peer-review: Externally peer-reviewed.

Conflict of Interest: The author has no conflict of interest to declare.

Grant Support: The author declared that this study has received no financial support.

\section{Kaynakça/References}

Albayrak, Muzaffer. 10 Ağustos 1915 Conkbayırı Süngü Hücumu. Ankara: Kültür ve Turizm Bakanlığı Yayınları, 2016.

Artists of the Great War. "Frank Crozier". Erişim 15 Mayıs 2021. https://artistsofthegreatwar.wordpress.com/2016/10/21/frank-crozier-c-1883-1948/ 
Australian Dictionary of Biography. "Lambert, George Washington”. Erişim 1 Nisan 2020. http://adb.anu.edu.au/biography/lambert-george-washington-7014

Australian War Memorial. “Major Zeki Bey”. Erişim 14 Mart 2021. https://www.awm.gov.au/collection/ART02868

Australian War Memorial. "Private Frank Rossiter Crozier”. Erişim 15 Mayıs 2021. https://www.awm.gov.au/collection/P10676272

Australian War Memorial. "The Landing at Anzac 25th April 1915”. Erişim 15 Mayss 2021. https://www.awm.gov.au/collection/C2091420

Australian War Memorial. “Australian Official War Artists”. Erişim 21 Haziran 2121. https://www.awm.gov.au/articles/encyclopedia/war_artists/ww1

Çanakkale Muharebeleri. “Çanakkale Muharebeleri”, Erişim 5 Ağustos 2018. https://canakkalemuharebeleri1915.com/

Çanakkale Muharebeleri. "Hain tepe”. Erişim 27 Şubat 2020. https:/canakkalemuharebeleri1915.com/genel/muharebe-alani-yer-isimleri/ariburnu/198-haintepe-plugge-s-plateau

Çanakkale Muharebeleri. "Sfenks". Erişim 24 Şubat 2020. https://canakkalemuharebeleri1915.com/genel/muharebe-alani-yer-isimleri/ariburnu/265-sfenksthe-sphinx

Çanakkale Muharebeleri. "Wellington Terrace”. Erişim 24 Şubat 2020. https://canakkalemuharebeleri1915.com/genel/muharebe-alani-yer-isimleri/ariburnu/495wellington-terasi-wellington-terrace

Gray, Anne. "Moore-Jones, Horace Millichamp". Dictionary of New Zealand Biography. 2015, Erişim 5 Ağustos 2018, https://teara.govt.nz/en/biographies/3m60/moore-jones-horace-millichamp

Jonathan Grant Gallery. “Australian Positions”. Erişim 7 Haziran 2019. http://jgg.co.nz/artist/australian-positions-extreme-right/

Haworth, Jennifer. Behind the Twisted Wire: New Zealand Artists in World War I. Christchurch, New Zealand: Wily Publications, 2016.

Kurşun, Zekeriya. "Çanakkale Muharebeleri”. İslam Ansiklopedisi. 8, İstanbul: Türkiye Diyanet Vakfi Yayınları, 1993, 205-208.

"Man With The Donkey". Evening Post, 15 September 1937. Erişim 15 Mayıs 2021. https://paperspast.natlib.govt.nz/newspapers/EP19370915.2.53

National Gallery of Australia. "Lambert”. Erișim 14 Mart 2021. https://nga.gov.au/exhibition/lambert/detail.cfm?IRN=144769 14

New Zealand History. “Moore-Jones' Gallipoli Landscapes”. Erişim 5 Ağustos 2018. https://nzhistory.govt.nz/media/photo/moore-jones-painting-of-gallipoli

Özakıncı, Cengiz. "25 Nisan 1985 Arıburnu, Anzak koyu, Mehmetçik ve Coniler”. Bütün Dünya 4 (2016): 57- 63.

Şahin, Çiğdem. "Çanakkale Savaşlarında İtilaf Kuvvetleri Üssü İmroz Adası (Gökçeada)". Savaş ve Toplum -Savaş Üzerine Yazılar. Konya: Eğitim Yayınevi, 2016, 219-244.

Templars Today. "Non Nobis Domine, Non Nobis, Sed Nomini Tuo Da Gloriam”. Erişim 11 Şubat 2020. https://www.templarstoday.org/2019/03/09/non-nobis-domine-non-nobis-sed-nomini-tuo-da-gloriam/

The Anzac Book. London: The Cassel Company Ltd., 1916. 
